University of New Hampshire

University of New Hampshire Scholars' Repository

\title{
Meta-analysis of fertilization experiments indicates multiple limiting nutrients in northeastern deciduous forests
}

\author{
Matthew A. Vadeboncoeur \\ University of New Hampshire - Main Campus, matt.vad@unh.edu
}

Follow this and additional works at: https://scholars.unh.edu/ersc

Part of the Forest Sciences Commons, and the Terrestrial and Aquatic Ecology Commons

\section{Recommended Citation}

Vadeboncoeur, M.A. 2010. Meta-analysis of fertilization experiments indicates multiple limiting nutrients in northeastern deciduous forests. Canadian Journal of Forest Research 40(9): 1766-1780.

This Article is brought to you for free and open access by the Institute for the Study of Earth, Oceans, and Space (EOS) at University of New Hampshire Scholars' Repository. It has been accepted for inclusion in Earth Systems Research Center by an authorized administrator of University of New Hampshire Scholars' Repository. For more information, please contact Scholarly.Communication@unh.edu. 


\title{
Meta-analysis of Fertilization Experiments Indicates Multiple Limiting Nutrients in Northeastern Deciduous Forests
}

\author{
Matthew A. Vadeboncoeur \\ Earth Systems Research Center \\ University of New Hampshire \\ matt.vad@unh.edu
}

\begin{abstract}
It is widely accepted that nitrogen limits primary production in temperate forests, although co-limitation by $\mathrm{N}$ and $P$ has also been suggested, and on some soils $\mathrm{Ca}$ and base cations are in short supply. I conducted a meta-analysis to assess the strength of existing experimental evidence for limitation of primary production by $\mathrm{N}, \mathrm{P}$, and $\mathrm{Ca}$ in hardwood forests of the northeastern United States and southeastern Canada, using data from 35 fertilization experiments in deciduous forests on glaciated soils across the region.

There is strong evidence for $\mathrm{N}$ limitation (formal meta-analysis weighted mean response ratio $=1.51, p<0.01$; simple mean $=1.42, p<0.001$ ). Forest productivity also tends to increase with additions of $\mathrm{P}$ ( $\operatorname{simple}$ mean $=1.15$, $p=0.05$ ) and $\mathrm{Ca}$ (simple mean $=1.36 p<0.001$ ). Across all treatments, $85 \%$ of response ratios were positive. Multiple-element additions had larger effects than single elements, but factorial experiments showed little evidence of synergistic effects between nutrient additions. Production responses correlated positively with the rate of $\mathrm{N}$ fertilization, but this effect was reduced at high rates of ambient $\mathrm{N}$ deposition.
\end{abstract}

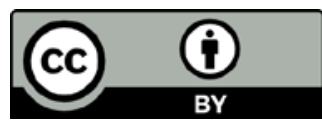

This reformatted accepted manuscript is made available by the author under a Creative Commons BY 3.0 License, in accordance with the author rights policy of NRC Research Press.

The formatted final version is available from the publisher at http://dx.doi.org/10.1139/X10-127

This document should be cited as:

Vadeboncoeur, M.A. 2010. Meta-analysis of fertilization experiments indicates multiple limiting nutrients in northeastern deciduous forests. Canadian Journal of Forest Research 40(9): 1766-1780. 


\section{Introduction}

Understanding nutrient limitations is a key goal of ecosystem science and is critical to predicting responses to environmental change. Because natural forest communities include multiple species and ages of trees, with varying nutrient requirements and acquisition strategies, nutrient limitation at the community scale is not as conceptually simple as it is for single organisms (Chapin et al. 1986). However, the effects of altered availability of various nutrients on net primary productivity (NPP) are relevant to a variety of ecosystem-scale questions (e.g. whether atmospheric $\mathrm{N}$ deposition increases rates of $\mathrm{CO}_{2}$ sequestration, or whether repeated removals of nutrient capital as biomass will reduce productivity). Globally, soil age is a key determinant of which nutrient limits productivity (Walker and Syers, 1976; Vitousek and Farrington 1997). Rock-derived elements such as $\mathrm{P}$ are less available in highly weathered soils, and while most soils lack bedrockderived $\mathrm{N}$, atmospheric deposition and $\mathrm{N}_{2}$ fixation provide exogenous $\mathrm{N}$ inputs to the soil. P-limitation is common in tropical systems, but it is rarely documented or even investigated in temperate forests on geologically young soils.

Responses to nutrient additions can be complex. If plants are able to dynamically allocate resources towards the acquisition of their most limiting nutrient(s), a plant at equilibrium would be equally limited by all resources (Bloom et al. 1985; Chapin et al. 1987). Altered allocation to acquisition of N, P, and $\mathrm{C}$ under fertilization are well documented (Treseder and Vitousek 2001; Treseder 2004). Classic "law of the minimum" limitation may occur if plants aren't completely successful at balancing allocation, but assuming some dynamic control of allocation to the acquisition of various resources, the next limitation should be encountered rather quickly after relief of primary limitation (Davidson and Howarth 2007). Furthermore, at the community scale, species composition is driven in part by competition among species for nutrients (Tilman 1985); long-term deficiencies in one nutrient will favor species with low requirements for it, or with mechanisms for efficiently acquiring or recycling it. Over time, nitrogen present in excess of demand is lost from ecosystems via leaching or denitrification (Vitousek and Howarth 1991). Systems without profound shortages of either $\mathrm{N}$ or $\mathrm{P}$ may therefore tend to approach co-limitation, in which the ratios of two or more available resources nearly match biotic demand (Vitousek and Farrington 1997; Davidson and Howarth 2007).

Recent global meta-analyses of fertilization experiments have confirmed that most terrestrial ecosystems increase NPP following $\mathrm{N}$ addition (LeBauer and Treseder 2008), but that $P$ limitation and $\mathrm{N}+\mathrm{P}$ co-limitation are also common (Elser et al. 2007). Unfortunately, few northeastern deciduous forests were included in these analyses; Elser et al. (2007) used only one, and LeBauer and Treseder (2008) included two. However, many fertilization experiments (e.g. Magill et al. 2004; Moore and Ouimet 2006; Pregitzer et al. 2008) have been conducted in this region since the pioneering work of Mitchell and Chandler (1939) at Black Rock Forest in New York.

Recently, many of the longest-run and most robust forest fertilization experiments have dealt with questions about the ecological and community effects of $\mathrm{N}$ saturation. Nitrogen-saturation theory predicts that forests receiving chronic $\mathrm{N}$ deposition will first respond with increased NPP, and then suffer a decline as the capacity of the system to store excess $\mathrm{N}$ in biomass and soils is exceeded (Aber et al. 1989). In late-stage $N$ saturation, forests may become P-limited (Mohren et al. 1986; Stevens et al. 1993), because $P$ is commonly the next-most-limiting nutrient after $\mathrm{N}$, and $\mathrm{P}$ availability is reduced with acidity. In the northeastern US, researchers have been concerned that the acidifying effects of chronic $\mathrm{N}$ and sulfur (S) deposition could lead to forest decline, due to both large leaching losses of base cations and increased mobility of toxic Al cations (Fenn et al. 2006). This raises the possibility of eventual Ca limitation, especially in managed forests where biomass removal and hydrologic export of nutrients following disturbance result in large net losses of nutrient capital, most dramatically for $\mathrm{Ca}$ (Federer et al. 1989).

Because of concerns about forest decline and nitrogen saturation, as well as a desire to manage forests for economic value, a large number of experiments have addressed the question of nutrient limitation in hardwood forests of the northeastern US and southeastern Canada, but their collective results have not yet been summarized statistically. Forests in the region are characterized by variation in $\mathrm{N}$ deposition, $\mathrm{pH}$, soil mineralogy, soil depth, and forest age and composition, making it 
difficult to draw general conclusions about nutrient limitation from any single fertilization study. For example, young forests may be more nutrient demanding relative to mineralization, and arbuscular mycorrhizal species might be more responsive to $\mathrm{N}$ availability than ectomycorrhizal species (Thomas et al. 2010) due to the inability of arbuscular mycorrhizal fungi to utilize soil organic N (Chalot and Brun 1998).

I used meta-analysis (Hedges et al. 1999) to synthesize results from 35 fertilization experiments covering a range of environmental conditions to determine the strength of existing evidence for $\mathrm{N}, \mathrm{P}$, and $\mathrm{Ca}$ limitation of primary production in hardwood forests. Meta-analysis is a powerful statistical tool that allows data compiled from many similar experiments to be used to infer the direction and magnitude of an effect, often with either greater statistical power or broader basis to draw general conclusions than is possible with a single experiment. I also examined whether the effects of fertilization differed significantly with the amount and form of fertilizer added, and with site characteristics such as the background rate of DIN deposition, species, and stand age. Finally, I used relevant subsets of the compiled data to determine whether there were significant synergistic effects when nutrients were added together (Elser et al. 2007; Davidson and Howarth 2007), and whether foliar N:P indicates the nutrient status of a stand.

\section{Methods}

\section{Study Region}

The area included in this study includes deciduousdominated forests on glaciated soils in the northeastern United States and southeastern Canada (Fig. 1). Only studies from sites on glaciated soils were included, because substrate age has a strong influence on the balance between nutrients derived from the atmosphere $(N)$ and those derived from rock (Walker and Syers 1976). Conifer forests were not included in this meta-analysis.

\section{Dataset Criteria}

Only studies describing the results of nutrient manipulations involving closed-canopy, hardwooddominated forests, plantations, or regenerating clearcuts were used. Pot and greenhouse experiments were not included, nor were studies of natural gradients in nutrient availability. All studies used included at least one fertilization with $\mathrm{N}, \mathrm{P}$, or $\mathrm{Ca}$, in known quantities per area, and reported data on at least one component of aboveground production (deciduous litterfall or woody biomass increment), or a proxy measurement (diameter, basal area, or volume increment) at the tree or plot scale. In the few cases where multiple publications described results from the same experiment, only the longest-term results were included. Additions of potassium $(\mathrm{K})$ and magnesium $(\mathrm{Mg})$ were also tracked, but were insufficient in number to warrant inclusion in the meta-analysis.

Searches on combinations of terms including "forest," "fertilization," "fertilizer," "limitation," "growth," "production," "nitrogen," "phosphorus," "calcium," "lime," "dolomite," and "NPK" were conducted using the ISI Web of Science database and Google Scholar. Relevant papers were searched for citations even when they did not include data that were usable in the meta-analysis. I found a total of 66 journal articles, gray literature reports, and theses describing fertilization studies in and near the study region, of which 35 met my criteria (Table 1). Because many studies report the results of multiple treatments (e.g. multiple rates or combinations of fertilizers), or divide their results by species without scaling to the stand level, this dataset includes 211 observations, each comprising production data from a treatment and a control. Where results were reported only as graphs, data were estimated by hand-measuring or with Engauge digitizing software http://digitizer.sourceforge.net/.

\section{Meta-analysis Methods}

Meta-analysis is a powerful technique for combining the results of many different studies (Arnqvist and Wooster 1995; Hedges et al. 1999), and is now commonly used in ecology to estimate the direction and magnitude of effects resulting from similar experimental manipulations (e.g. LeBauer and Treseder 2008; Nave et al. 2010). The first step of any meta-analysis is to standardize treatment effects as "response ratios", which allow the comparison of data that are reported using different metrics (Hedges et al. 1999). A response ratio $(R)$ is calculated for each treatment result reported, as the ratio of production under fertilization to production under control conditions. When possible, I used pretreatment data to normalize for plot differences 
(Salonius et al. 1982). An increase in production with fertilization corresponds to response ratio $R>1$, and a decrease to $R<1$. Positive and negative responses reported as statistically significant were tallied for each nutrient or nutrient combination added ( $\mathrm{N}$ alone, $\mathrm{N}$ plus other nutrients, $\mathrm{P}$ alone, $\mathrm{P}$ plus other nutrients, $\mathrm{Ca}$ alone, and Ca plus other nutrients; note that "P alone" includes phosphate fertilizers that contain some $\mathrm{Ca}$ ).

In 20 studies the data necessary to conduct a full, statistically valid meta-analysis (sample size and standard deviation of each measured variable) were not reported. I therefore began with an inclusive but relatively simple methodology, following Elser et al. (2007), in which all observations are given equal weight in calculating means and confidence intervals for $R$. Response ratios were In-transformed to normalize the sampling distribution before averaging (Hedges et al. 1999), and confidence intervals are therefore asymmetric. This method was used to analyze all data by addition type (each element alone and in combination with others), and to calculate the mean response to each element by species. Three observations could not be included because $\ln (R)$ is undefined when production data for either the control or treatment are negative (net production data are sometimes negative due to mortality). Two-sided $t$-tests on $\ln (R)$ were used to compare differences between simple mean response ratios.

Fifteen studies (including 98 observations) reported data sufficient for inclusion in a more rigorous metaanalysis following the methodology outlined by Hedges et al. (1999). Briefly, $R$ was In-transformed and sample size and variance data are used to calculate a weight. The weighted mean logged response ratio and its standard error were then calculated, taking into account within- and betweenexperiment variances. Finally, these results were reported as response ratios by taking the antilog of the means and confidence interval limits. Two-tailed $p$-values for each response ratio were calculated using the standard error of each weighted mean $\ln (R)$ and Student's $t$-distribution.

\section{Regression Analysis}

I used single and multiple linear regression to determine whether relationships existed between the response ratio and stand age, DIN deposition rate, whether fertilization was continual or a single pulse, whether measurements were made at the scale of individual trees or whole stands, the mean annual and cumulative amount of each element added, experimental duration, interactions between DIN deposition and each nutrient addition, and 2way interactions among the nutrient additions. Rates of $\mathrm{N}$ deposition are inconsistently reported in the 35 studies, so modern $\mathrm{N}$ deposition at each study location was estimated from a kriged interpolation (calculated in ArcGIS 9.1) of 1999-2008 mean DIN at 58 NADP sites (USA), and 12 CAPMoN sites (Canada). For earlier experiments, interpolated current DIN estimates were reduced by $2.1 \%$ for each decade they preceded the year 2000 , based on the long-term trend in $\mathrm{N}$ deposition reconstructed by Bowen and Valiela (2001). Backward stepwise multiple regression based on Akaike's information criterion was used to arrive at the best parsimonious linear model.

\section{Other statistical tests}

One-way ANOVAs were performed on Intransformed response ratios to determine whether there were significant differences in response ratios by the metric used to assess production response ( $n$ $=208$ in 6 categories: diameter, basal area, volume, biomass, foliage, and total ANPP), or by the form of $\mathrm{N}$ fertilizer added ( $n=97$ in 4 categories: $\mathrm{NH}_{4}$ only, $\mathrm{NO}_{3}$ only, $\mathrm{NH}_{4} \mathrm{NO}_{3}$, and urea).

I tested whether strong co-limitation was indicated by synergistic effects as found by Elser et al. (2007) with a much smaller meta-analysis on the seven studies that reported factorial results. For each study, $R_{\mathrm{NP}}, R_{\mathrm{PCa}}$, and $R_{\mathrm{NPCa}}$ were calculated as the ratio of the combined effect to the largest singleelement effect. As in the larger simple metaanalysis, response ratios were In-transformed before calculating unweighted means.

To test the hypothesis that foliar N:P ratio can be used to separate $\mathrm{N}$-limited from $\mathrm{P}$-limited plants (Güsewell 2004), I ran a linear regression on the Ponly response ratio against the control foliage N:P (mass basis) where reported $(n=8)$.

\section{Results}

\section{Meta-analysis}

In the simple analysis of 208 observations, all categories of additions resulted in significant increases $(\alpha=0.05)$ in aboveground productivity 
(Fig. 2a). The mean response ratio for $\mathrm{N}$ with other nutrients (1.70) was significantly greater $(p=0.01)$, than for experiments that added $\mathrm{N}$ alone (1.42). Additions of $P$ with other nutrients had an average response ratio of 1.61, which is significantly ( $p<$ $0.001)$ greater than that for $P$ alone (1.15). The difference between mean response to additions of Ca alone (1.44) versus with other nutrients (1.68) was of marginal significance $(p=0.06)$.

The more statistically rigorous meta-analysis (98 observations), also showed that average responses to all nutrient additions were positive, though not all effects were significant (Fig. 2b). Additions of $\mathrm{N}$ alone significantly increased NPP on average $(p<$ 0.01 ), but additions of $\mathrm{Ca}$ or $\mathrm{P}$ with or without other nutrients, or of $\mathrm{N}$ with other nutrients, did not have significant effects on average. This may be due in part to small sample sizes (Table 2), especially for Ponly fertilizations ( $n=3$; the extremely large confidence interval is a consequence of running the In-transformed meta-analysis with so few observations). There was a significant effect of Ca addition when all observations (with and without other nutrients; $n=31 ; p=0.03$ ) were combined. Overall, $85 \%$ of response ratios observed for both single-element and multiple-element additions are $>$ 1 (In response ratio $>0$ ), and the shapes of these curves are generally similar (Table 2; Fig. 3 ).

Nine of 12 species with multiple single-species observations significantly increased production in response to $\mathrm{N}$ alone (Table 3 ). Neither of the species with multiple P-only additions increased production significantly, and of six species in which Ca was added alone, only sugar maple (Acer saccharum Marsh.) increased production significantly (Table 3). Mixed-species stands showed significant production increases in response to $\mathrm{N}$-only additions and to mixed-element additions overall, but not to P-only additions.

\section{Multiple Regression}

Individually, stand age and the rate of DIN deposition showed significant negative linear relationships with the response ratio (Table 4). In the full multiple regression model, which included 11 terms and 6 interactions, only the annual and cumulative $\mathrm{N}$ addition rates had significant positive effects. Backward stepwise multiple regression eliminated all terms except the annual rate of $\mathrm{N}$ addition and a significant negative interaction between this term and DIN deposition. While highly significant $(p<0.001)$, the reduced model explained very little of the total variance in response ratios; the adjusted $R^{2}$ was 0.09 .

\section{Other statistical tests}

The production metric used (diameter, basal area, volume, biomass, foliage, or total ANPP) significantly affected response ratios (ANOVA $n=208, F=3.54, p$ $<0.01$ ). The form of $\mathrm{N}$ fertilizer added had no significant effect on response ratios (ANOVA $n=97$; $F=1.04 ; p=0.37$ ). Response ratios in the multiplenutrient treatments of factorial experiments were not significantly greater than the single-nutrient additions: $R_{\mathrm{NP}}=1.05(n=10 ; p=0.83), R_{\mathrm{PCa}}=1.02(n$ $=7, p=0.82)$, and $R_{\mathrm{NPCa}}=1.09(n=6 ; p=0.72)$. There was not a significant linear relationship between the $\mathrm{N}: \mathrm{P}$ ratio of control foliage and P-only response ratio $\left(n=8 ; p=0.65 ; R^{2}=0.04\right)$.

\section{Discussion}

\section{Production Responses to $\mathbf{N}$}

Nitrogen limitation was tested in 100 observations, with $R>1$ in 84 . Of 34 observations with an $\mathrm{N}$ effect reported as significant, 31 had $R>1$ (Table 2). Lebauer and Treseder (2008) found that, globally, temperate forests increased production $19 \%$ on average in response to $\mathrm{N}$ fertilization. Elser et al. (2007) report a similar result ( $25 \%)$ for terrestrial ecosystems in general. In this meta-analysis, additions of $\mathrm{N}$ alone resulted in somewhat greater but not significantly different increases in production (42-51\%; Fig. 2). However, in contrast with the findings of Elser et al. (2007), adding $N$ in combination with other nutrients did not significantly increase the mean effect (Fig. 2).

The amount of $\mathrm{N}$ added annually was identified by the reduced multiple linear regression model (Table 4 ) as the only factor significantly affecting the response ratio, along with a negative interaction term that indicates the effect of $\mathrm{N}$ fertilization was reduced where atmospheric DIN deposition was high. Mean annual $\mathrm{N}$ additions varied widely (14$970 \mathrm{~kg} \mathrm{~N} \mathrm{ha}^{-1} \mathrm{y}^{-1}$; Fig. 4a), and usually greatly exceeded ambient DIN deposition (2-10 kg N ha ${ }^{-1} \mathrm{y}$ $\left.{ }^{1}\right)$. Cumulative $\mathrm{N}$ addition had a significant effect independent of annual $\mathrm{N}$ addition rate in the full multiple regression model, but was not included in the final regression. The large cumulative $\mathrm{N}$ 
additions in some experiments (up to $2100 \mathrm{~kg} \mathrm{ha}^{-1}$ ) raise the question of why forests should still respond to $\mathrm{N}$ additions. Hydrologic and atmospheric losses of $\mathrm{N}$ (Vitiousek and Howarth 1991) might remove some of the added $\mathrm{N}$, or alternatively $\mathrm{N}$ might be a resource useful in acquiring other nutrients (e.g. $\mathrm{N}$ rich phosphatase enzymes; Treseder and Vitousek 2001).

The assembled data show that positive responses to $\mathrm{N}$ outnumber negative responses at all annual fertilization rates (Fig. 4a). This is somewhat surprising because declining production is a hypothesized consequence of late-stage $\mathrm{N}$ saturation (Aber et al. 1989). However, no such effects have been shown for hardwood forests in North America under current $\mathrm{N}$ deposition rates (Fenn et al. 2006). Magnani et al. (2007) found a strong positive relationship between $\mathrm{N}$ deposition and net ecosystem production at deposition rates similar to those in the study region, and Thomas et al. (2010) report that the growth of several deciduous species correlates positively with $\mathrm{N}$ deposition rate. In one $\mathrm{N}$ addition study I included, increased mortality was responsible for a decline in production (reported as live aboveground biomass increment) in stands receiving 50-100 kg N ha ${ }^{-1} \mathrm{y}^{-1}$ (Wallace et al. 2007). Increased production in the remaining trees could either be due to fertilization or simply to the thinning effect of fertilizer-induced mortality.

Nitrogen was most commonly added as ammonium nitrate $\left(\mathrm{NH}_{4} \mathrm{NO}_{3}\right)$, and occasionally as sodium nitrate $\left(\mathrm{NaNO}_{3}\right)$, Calcium nitrate $\left(\mathrm{Ca}\left(\mathrm{NO}_{3}\right)_{2}\right)$, ammonium sulfate $\left(\left(\mathrm{NH}_{4}\right)_{2} \mathrm{SO}_{4}\right)$, urea $\left(\left(\mathrm{NH}_{2}\right)_{2} \mathrm{CO}\right)$, or as "complete NPK" fertilizer in which the form of $\mathrm{N}$ is not reported. Similar to the findings of Lebauer and Treseder (2008), the form of $\mathrm{N}$ fertilizer added did not significantly influence response ratios in this study.

\section{Production Responses to P Fertilization}

Elser et al. (2007) report that the mean response of terrestrial ecosystems to $\mathrm{P}$ addition is a $\sim 25 \%$ increase in production. In the current study, the mean effect of adding $P$ alone was 15\% (using inclusive methodology; Fig. $2 a ; p=0.03$ ), or a nonsignificant $4 \%$ (using more rigorous methods on a much smaller dataset; Fig. 2b). The smaller effects of $P$ relative to $\mathrm{N}$ in the study region may be related soil mineralogy. For example, soils on granitic till contain substantial primary mineral $\mathrm{P}$ as apatite, which may be an important source of Ca (Blum et al.
2002). On the other hand, in unglaciated soils just south of the study region in Pennsylvania, Auchmoody (1982) found evidence for N+P colimitation in black cherry, though Ward and Bowersox (1970) found no response to $P$ alone in mixed oaks.

The one significant response to a P-only addition in the meta-analysis data set was in 14-year-old quaking aspen (Safford and Czapowskyj 1986), suggesting that $P$ limitation might occur mostly in young forests. Naples and Fisk (2010) found root ingrowth responses to $\mathrm{P}$ in regenerating but not mature hardwood stands in New Hampshire, and studies of birch seedlings potted in forest soil responded to $\mathrm{N}, \mathrm{P}$, and $\mathrm{N}+\mathrm{P}$ fertilizations (Hoyle 1969; Safford 1982). St.Clair et al. (2008) comment that young sugar maples may be more susceptible than mature trees to $P$ limitation. While Gradowski and Thomas (2008) inferred P limitation in mature sugar maples based on vector analysis and shoot extension, diameter increment (used in the metaanalysis) did not show a significant response to $P$ fertilization. Whether regenerating forests pass through a P-limited stage under certain conditions deserves further research.

Phosphorus is typically added as triple superphosphate $\left(\mathrm{Ca}\left(\mathrm{H}_{2} \mathrm{PO}_{4}\right)_{2}\right)$. No experiments in my data set added $\mathrm{P}$ without also adding $\mathrm{Ca}$ in this form, making it difficult to draw conclusions about the effect of $\mathrm{P}$ alone on ecosystem productivity. Further complicating matters, $\mathrm{P}$ added in soluble form can be rapidly immobilized through sorption to secondary minerals (Jiao et al. 2007). P additions varied from 6 - $200 \mathrm{~kg} \mathrm{P} \mathrm{ha}^{-1} \mathrm{yr}^{-1}$ (Fig. 4b), and positive responses to $\mathrm{P}$ occurred at all but the highest fertilization rates, for which there are few observations. Some have reported increased foliar P concentrations with fertilization (Mercer 1974; Safford and Filip 1974; Ellis 1979; Safford and Czapowskyj 1986; Fahey et al. 1998; Gradowski and Thomas 2008), indicating that fertilization did significantly increase $P$ availability. However, others (Finn and White 1966; Schmitt et al. 1981; Leech and Kim 1990; Ouimet and Fortin 1992) found no such increase, which is consistent either with Psufficiency in the control trees, or with insufficient $P$ availability relative to other added nutrients.

Among "P-only" fertilizations, two-thirds of responses are positive (Fig. 3; Table 2). Such gains in aboveground NPP might be due in part to reduced carbon allocation to mycorrhizal fungi. A meta- 
analysis by Treseder (2004) found that average mycorrhizal abundance decreased by $32 \%$ under $P$ fertilization, and allocation to mycorrhizal fungi comprised up to $20 \%$ of total NPP in field studies reviewed by Hobbie (2006).

Some have suggested that high foliar N:P ratios imply P-limitation; Güsewell (2004) reviewed these claims and found that $\mathrm{N}$ limitation often occurs at $\mathrm{N}: \mathrm{P}<10$, and $\mathrm{P}$ limitation at $\mathrm{N}: \mathrm{P}>20$ (mass basis). I found little support for this idea. There was no significant relationship between foliar $\mathrm{N}: \mathrm{P}$ and the response to $P$ fertilization. While no study in this data set had a foliar N:P > 20, the only study with a significant response to $P$ alone (Safford and Czapowskyj 1986), actually had the lowest foliar N:P ( 7).

\section{Production Responses to Calcium Fertilization}

Like additions of $\mathrm{N}$ and $\mathrm{P}$, additions of Ca had mostly positive effects (Fig. 3 ) across a wide range of fertilization rates (Fig. 4c). Under the rigorous metaanalysis, only the combination of all observations ( $\mathrm{Ca}$ alone and with other elements) was significantly different from no effect (Fig. 2b), though this may be attributable to the larger sample size, as the mean response ratio did not differ much between the two categories. Using the more inclusive data set, additions of $\mathrm{Ca}$ with other nutrients tended to show a greater mean response than $\mathrm{Ca}$ alone, though this was not statistically significant (Fig. 2a).

Calcium limitation is inherently difficult to study because most forms of $\mathrm{Ca}$ fertilizer increase soil $\mathrm{pH}$, which in turn affects the availability of other important ions, including both nutrients and potentially toxic elements. For example, the solubility of rhizotoxic $\mathrm{Al}^{3+}$, sorption of $\mathrm{PO}_{4}{ }^{3-}$, nitrification, enzyme activities, and microbial community composition are all sensitive to $\mathrm{pH}$ (Sparks 2003; Paul 2007).

In the studies reviewed here, calcium was added in various forms, most commonly as calcite $\left(\mathrm{CaCO}_{3}\right)$ or dolomite $\left((\mathrm{Ca}, \mathrm{Mg}) \mathrm{CO}_{3}\right)$, but also as wollastonite $\left(\mathrm{CaSiO}_{3}\right)$, gypsum $\left(\mathrm{CaSO}_{4}\right)$, calcium nitrate, or calcium chloride $\left(\mathrm{CaCl}_{2}\right)$. Of these, only $\mathrm{CaCl}_{2}$ does not affect soil $\mathrm{pH}$. Increases in $\mathrm{pH}$ of 0.1 to 0.5 units were reported following additions of $50-1600 \mathrm{~kg} \mathrm{Ca} \mathrm{ha}^{-1}$ (Fyles et al. 1994; Wilmot et al. 1996; Juice et al. 2006; Gradowski and Thomas 2008), though Safford and Czapowskyj (1986) report that O horizon $\mathrm{pH}$ increased from 4.3 to 6.1 with the addition of $\sim 900$ $\mathrm{kg} \mathrm{Ca} \mathrm{ha}{ }^{-1}$ as dolomite. The effects of most calcium additions on $\mathrm{pH}$ make it impossible to determine whether increased NPP was caused by relief of Calimitation in the strict sense, or indirectly by $\mathrm{pH}$ changes that increased the availability of other macro- and micro-nutrients, reduced Al availability, or altered the ecological relationships governing various biogeochemical process rates. The single study that added $\mathrm{Ca}$ as $\mathrm{CaCl}_{2}$ (Kobe et al. 2002) reported increased seedling growth with fertilization, though the effect was significant for only one of three hardwood species measured.

\section{Fertilization Responses by Species}

Sugar maple was the most studied species in the data set (26 studies), reflecting concern about the apparent region-wide decline of this economically important species (Houston 1987). The speciesspecific meta-analysis indicates significant positive effects of $\mathrm{Ca}$ fertilization and multiple-nutrient fertilization on sugar maple production, but no significant effect from $\mathrm{N}$ or $\mathrm{P}$ fertilization alone (Table 3). That various researchers have implicated several different nutrient deficiencies in sugar maple decline either implies multiple causes, or that region-wide phenomena such as acid deposition (Fenn 2006), drought (Payette et al. 1996) or increased soil freezing (Boutin and Robitaille 1995) can exacerbate deficiencies of nutrients already low in supply depending on local stand and soil characteristics. For example, Mader et al. (1969) recommended $\mathrm{N}$ fertilization, even in acidifying forms such as $\left(\mathrm{NH}_{4}\right)_{2} \mathrm{SO}_{4}$, for declining sugar maple. Others blame the decline on cation leaching induced by acidic $\mathrm{N}$ and $\mathrm{S}$ deposition (Fyles et al. 1994; Wilmot et al. 1996; Moore and Ouimet 2006), recommending addition of $\mathrm{CaCO}_{3}$ alone or with $\mathrm{K}$ and Mg. Paré and Bernier (1989) and Gradowski and Thomas (2006) report P deficiency in sugar maple. Due to the influence of human land-use, sugar maple may now occur on sites to which it is poorly suited (Houston 1999); it has increased in abundance since presettlement (Cogbill et al. 2002).

The number of species-by-nutrient combinations with no data in Table 3, along with those with no confidence interval (i.e. $n=1$ ) highlights the need for further work. Species in the region differ in nutrient ratios and their effects on soil cycling of nutrients (Lovett et al. 2004), which might influence their responses to chronic changes in nutrient availability, though this idea has not been extensively tested. 
Even among species with large numbers of observations, differences in response ratios should not be over-interpreted. For example, birch and aspen studies were mostly conducted in young stands while many sugar maple studies were conducted in declining mature stands. Thomas et al. (2010) found that arbuscular mycorrhizal species responded more strongly to chronic $\mathrm{N}$ deposition, but here ectomycorrhizal species showed nonsignificantly greater responses to $\mathrm{N}$ fertilization than did arbuscular mycorrhizal species (Table 3).

\section{Effect of Stand Age}

When analyzed in isolation, there was a significant negative effect of stand age on $R$ (Table 4), suggesting that seedlings or young stands may tend to have greater response ratios than older stands when fertilized. In young stands, responses to fertilization may be greater because high overall nutrient demand has led to strong nutrient limitation of production, whereas most nutrient demand in mature stands is satisfied by recycling of nutrients. However, this effect was not significant in the full multiple regression, and was dropped in the course of backwards stepwise regression (Table 4).

\section{Influence of Mensuration Methods}

The use of response ratios in meta-analyses is intended to minimize the effect of different metrics among studies. In this study, production in treatment and control plots was variously reported as diameter increment, basal area increment, volume increment, wood biomass increment, foliar production, and total aboveground (wood + foliage) production. While most of these metrics are based on measurement of diameter increment, different mathematical transformations could result in different reported response ratios for a similar response. An ANOVA indicated that response ratios varied significantly with the type of measurement. Specifically, basal area increment response ratios were significantly smaller than diameter and volume increment responses.

Most studies included in this meta-analysis were replicated at the tree level. Selected trees were measured before and after fertilization, or sampled with increment borers after treatment. When sample sizes are small, mortality over the treatment period is likely to be missed, and the reported aboveground production represents that of the surviving trees only. This is especially true if trees are selected at the end of the treatment period, or if vigor criteria are employed. Where fertilization increases mortality (e.g. Magill et al. 2004; Wallace et al. 2007), or in young stands undergoing thinning, mean surviving-tree production may be much greater than the stand-level live biomass increment. This effect may in part explain the greater increases in young stands than mature stands, though it would also be expected to lead to greater increases with longer study length, which was not observed. This bias can be avoided in future studies by reporting both tree-level and stand-level production data.

\section{Multiple Resource Limitation}

At the broad scale, if a system is limited primarily by one nutrient, NPP will respond to addition of only that nutrient, but may show larger responses to combined additions once primary limitation is relieved. A system that is co-limited by two nutrients will respond modestly to additions of either nutrient, and more strongly when the two are added together (Davidson and Howarth 2007), until a third limitation is encountered. Globally, the mean response of terrestrial ecosystems to $\mathrm{N}+\mathrm{P}$ was more than twice the response to either nutrient alone (Elser et al. 2007). Positive production responses occurred with the single addition of all three elements examined here (Fig. 2). This pattern implies that these forests are co-limited at least in the sense that resources are allocated to obtaining these nutrients in optimal ratios, and that altered availability allows the reallocation of valuable carbon.

The observation that multiple nutrient additions result in larger NPP increases than single nutrient additions (Fig. 2) initially appears to support the results of Elser et al. (2007). However, the singleand multiple-element experiments are not necessarily from the same locations or even in the same forms or amounts. The small meta-analysis I ran on the factorial experiments yielded no significant effects, so the synergistic pattern observed globally by Elser et al. (2007) is not strongly supported by this regional data set. Still, the small but generally positive effects of $\mathrm{P}$ and $\mathrm{Ca}$ fertilization without $\mathrm{N}$ indicate some degree of co-limitation with $\mathrm{N}$ in these forests (Figs. 2 and 3). These forests can be interpreted as being strongly limited by $\mathrm{N}$, and more weakly limited by $\mathrm{P}$ and $\mathrm{Ca}$ (or other factors 
that change with soil $\mathrm{pH}$ ) even in the absence of synergistic effects.

The law of the minimum is a description of resource limitation at a moment in time. For example, regardless of nutrient availability, a tree is always limited by light at night, and may sometimes be limited by water or temperature. In the short term, any of several factors may limit NPP, but experiments conducted at annual or longer time scales will only identify nutrients that become limiting when conditions are otherwise optimal for photosynthesis. Furthermore there can be complex interactions among limitations. Hypothetically one nutrient might increase the maximum photosynthesis rate, while another improves cold tolerance, both leading to increased production on an annual time step. Alternatively, carbon allocated to acquisition of one nutrient can be re-allocated toward another (e.g. changing rooting distribution), or one nutrient may itself be a resource for acquiring another (e.g. $\mathrm{N}$ allocated to phosphatase enzymes). Lags in such re-optimization of resources further complicate the matter. Understanding the interactions among these factors and other limiting resources is a vital challenge for ecosystem ecology, particularly given the rapid anthropogenic alterations of biogeochemical cycles.

\section{Potential Biases}

The "file drawer problem," a bias against publishing non-significant results, is a drawback of most metaanalyses, which can't include inaccessible or hidden data (Rosenthal 1979). The effect of unpublished non-significant results is reduced when, as done here, the search for relevant data includes conference proceedings, experiment station bulletins, and unpublished graduate theses, rather than limiting the scope to peer-reviewed journals. This problem is also mitigated when multiple results (e.g. different fertilization rates or combinations) are reported in a single paper, as in 27 of 35 studies included here. Moreover, if the effect of fertilization truly were zero, there would be as many significantly negative responses as significantly positive ones, and it seems unlikely that data showing significantly reduced production with fertilization would go unpublished.

As with any meta-analysis, conclusions can only be drawn for the ecosystems collectively sampled. Clearly, sampling is non-random, both geographically (Fig. 1) and by species (Table 3). Differences in the magnitude and direction of response are likely the result of real differences in species, stand age, disturbance history, hydrologic inputs and outputs, soil chemistry, as well as interannual variability, sampling error, and measurement error. Still, this is the best that can be done to synthesize nutrient limitation data regionally: a thorough search for results both published and unpublished within a well-defined biogeographic region.

\section{Conclusions and Recommendations}

The results presented here strongly support the hypothesis that nitrogen limits production in deciduous forests of the northeast, but suggest it is not the only limiting nutrient. Rather, the forests studied appear to increase productivity in response to all studied nutrients (Figs. 2 and 3). Fertilizations with multiple elements generally show larger results than those of single elements (Fig. 2), though factorial studies show no evidence of synergistic relief of co-limitation. Responses to $P$ additions are relatively modest, and there is no evidence in these data that they can be predicted using foliar $N: P$ ratios. Responses to Ca were generally positive. However, the data were insufficient to separate the effects of increased Ca availability from concomitant increases in soil $\mathrm{pH}$.

Future studies should, as resources allow, be designed in such a way that the mechanisms behind the results can be better understood and compared among research sites. Specifically:

- $\quad$ Studies intended to determine which nutrient limits production should ideally have a full factorial design (e.g. control, $+N,+P$, and $+N+P$ ).

- Phosphorus should be added in a form that does not contain calcium, such as $\mathrm{NaH}_{2} \mathrm{PO}_{4}$.

- To separate the effects of Ca fertilization from soil $\mathrm{pH}$ changes, a pH-only manipulation should be added as a reference, for example using $\mathrm{Na}_{2} \mathrm{CO}_{3}$. Alternatively, $\mathrm{Ca}$ can be added as $\mathrm{CaCl}_{2}$ without affecting soil $\mathrm{pH}$.

- $\quad$ To separate the effects of $\mathrm{N}$ additions from $\mathrm{pH}$ shifts, $\mathrm{N}$ could be added in forms that differ in the magnitude of their $\mathrm{pH}$ effects, such as $\left(\mathrm{NH}_{4}\right)_{2} \mathrm{SO}_{4}$ and urea. Nitrogen-free acidification treatments could also prove useful in disentangling the effects of $\mathrm{pH}$ and $\mathrm{N}$. 
- $\quad$ To account for mortality and changing competition dynamics resulting from treatment, effects on NPP should be expressed both on an individual tree and a whole-stand level. All trees should be tagged and measured before and after treatment. Study plots should be as large as is practical, and randomized-block layouts should be employed.

- Means, sample sizes and variance data should be reported for all treatments, even when not significantly different from the control, to allow inclusion in future meta-analyses.

- While convenient, metrics such as radial increment or basal area increment are difficult to compare among stands and trees of different ages. Allometric equations can be used to express these results in more biogeochemically relevant terms, such as biomass increment.

\section{Acknowledgements}

I thank Erik Hobbie, Scott Ollinger, Mariann Johnston, Christy Goodale, Adrien Finzi, and two anonymous reviewers for comments and insights that improved this manuscript. Support for was provided in part by NSF grant DEB0614266.

\section{References}

Aber, J.D., Nadelhoffer, K.J., Steudler, P., and Melillo, J.M. 1989. Nitrogen Saturation in Northern Forest Ecosystems. BioScience 39: 378-386.

Arnqvist, G., and Wooster, D. 1995. Meta-analysis: synthesizing research findings in ecology and evolution. Trends in Ecology \& Evolution 10: 236-240. doi:10.1016/S0169-5347(00)89073-4.

Auchmoody, L.R. 1982. Response of young black cherry stands to fertilization. Can. J. For. Res. 12: 319-325. doi:10.1139/x82-046.

Bigelow, S., and Canham, C. 2007. Nutrient limitation of juvenile trees in a northern hardwood forest: Calcium and nitrate are preeminent. For. Ecol. Manage. 243: 310-319. doi:10.1016/j.foreco.2007.03.027.

Bloom, A.J., Chapin, F.S., and Mooney, H.A. 1985. Resource Limitation in Plants-An Economic Analogy. Annu. Rev. Ecol. Syst. 16: 363-392. doi:10.1146/annurev.es.16.110185.002051.

Blum, J.D., Klaue, A., Nezat, C.A., Driscoll, C.T., Johnson, C.E., Siccama, T.G., Eagar, C., Fahey, T.J., and Likens, G.E.
2002. Mycorrhizal weathering of apatite as an important calcium source in base-poor forest ecosystems. Nature 417: 729-731. doi:10.1038/nature00793.

Boutin, R., and Robitaille, G. 1995. Increased soil nitrate losses under mature sugar maple trees affected by experimentally induced deep frost. Can. J. For. Res. 25: 588-602. doi: 10.1139/x95-066.

Bowen, J.L., and Valiela, I. 2001. Historical changes in atmospheric nitrogen deposition to Cape Cod, Massachusetts, USA. Atmos. Environ. 35: 1039-1051. doi:10.1016/S1352-2310(00)00331-9.

Chalot, M., and Brun, A. 1998. Physiology of organic nitrogen acquisition by ectomycorrhizal fungi and ectomycorrhizas. FEMS Microbiol. Rev. 22: 21-44. doi: 10.1111/j.1574-6976.1998.tb00359.x.

Chapin, F.S., Bloom, A.J., Field, C.B., and Waring, R.H. 1987. Plant responses to multiple environmental factors. BioScience 37: 49-57.

Chapin, F.S., Vitousek, P.M., and Cleve, K.V. 1986. The nature of nutrient limitation in plant communities. Am. Nat. 127: 48-58.

Cogbill, C.V., Burk, J., and Motzkin, G. 2002. The forests of presettlement New England, USA: spatial and compositional patterns based on town proprietor surveys. J. Biogeogr. 29: 1279-1304. doi:10.1046/j.13652699.2002.00757.x.

Côté, B., Halloran, I.O., Hendershot, W.H., and Spankie, H. 1995. Possible interference of fertilization in the natural recovery of a declining sugar maple stand in southern Quebec. Plant Soil 168-169: 471-480. doi:10.1007/BF00029359.

Davidson, E.A., and Howarth, R.W. 2007. Nutrients in synergy. Nature 449: 1000-1001. doi:10.1038/4491000a.

Dyke, A.S., Moore, A., and Robertson, L. 2003. Deglaciation of North America. Geological Survey of Canada, Open File 1574.

Ellis, R.C. 1979. Response of crop trees of sugar maple, white ash, and black cherry to release and fertilization. Can. J. For. Res. 9: 179-188. doi:10.1139/x79-032.

Elser, J.J., Bracken, M.E., Cleland, E.E., Gruner, D.S., Harpole, W.S., Hillebrand, H., Ngai, J.T., Seabloom, E.W., Shurin, J.B., and Smith, J.E. 2007. Global analysis of nitrogen and phosphorus limitation of primary producers in freshwater, marine and terrestrial ecosystems. Ecol. Lett. 10: 1135-1142. doi:10.1111/j.1461-0248.2007.01113.x.

Elvir, J.A., Wiersma, G.B., White, A.S., and Fernandez, I.J. 2003. Effects of chronic ammonium sulfate treatment on basal area increment in red spruce and sugar maple at the Bear Brook Watershed in Maine. Canadian 
Journal of Forest Research 33: 862-869. doi:10.1139/x03-016.

Fahey, T.J., Battles, J.J., and Wilson, G.F. 1998. Responses of early successional northern hardwood forests to changes in nutrient availability. Ecol. Monogr. 68: 183212. doi:10.1890/00129615(1998)068[0183:ROESNH]2.0.CO;2.

Federer, C.A., Hornbeck, J.W., Tritton, L.M., Martin, C.W., Pierce, R.S., and Smith, C.T. 1989. Long-term depletion of calcium and other nutrients in eastern US forests. Environ. Manage. 13: 583-601. doi:10.1007/BF01874965.

Fenn, M.E., Huntington, T.G., Mclaughlin, S.B., Eagar, C., Gomez, A., and Cook, R.B. 2006. Status of soil acidification in North America. J. For. Sci. 52: 3-13.

Finn, R.F., and Tyron, H.H. 1942. The comparative influence of leaf mould and inorganic fertilizers on the growth of red oak. Black Rock Forest Papers 1(17).

Finn, R.F., and White, D.P. 1966. Commercial fertilizers increase growth in a yellow-poplar plantation. J. For. 64: 809-810.

Finzi, A.C. 2009. Decades of atmospheric deposition have not resulted in widespread phosphorus limitation or saturation of tree demand for nitrogen in southern New England. Biogeochemistry 92: 217-229. doi:10.1007/s10533-009-9286-z.

Fyles, J.W., Côté, B., Courchesne, F., Hendershot, W.H., and Savoie, S. 1994. Effects of base cation fertilization on soil and foliage nutrient concentrations, and litter-fall and throughfall nutrient fluxes in a sugar maple forest. Can. J. For. Res. 24: 542-549. doi:10.1139/x94-071.

Gradowski, T., and Thomas, S.C. 2006. Phosphorus limitation of sugar maple growth in central Ontario. For. Ecol. Manage. 226: 104-109. doi:10.1016/j.foreco.2005.12.062.

Gradowski, T., and Thomas, S.C. 2008. Responses of Acer saccharum canopy trees and saplings to $P, K$ and lime additions under high N deposition. Tree Phys. 78: 173185. doi:10.1093/treephys/28.2.173.

Gress, S.E., Nichols, T.D., Northcraft, C.C., and Peterjohn, W.T. 2007. Nutrient limitation in soils exhibiting differing nitrogen availabilities: what lies beyond nitrogen saturation? Ecology 88: 119-130. doi:10.1890/0012-9658(2007)88[119:NLISED]2.0.CO;2.

Güsewell, S. 2004. N : P ratios in terrestrial plants: variation and functional significance. New Phytol. 164: 243-266. doi:10.1111/j.1469-8137.2004.01192.x.

Hedges, L.V., Gurevitch, J., and Curtis, P.S. 1999. The MetaAnalysis of Response Ratios in Experimental Ecology. Ecology 80: 1150-1156. doi:10.1890/0012658(1999)080[1150:TMAORR]2.0.CO;2.
Hobbie, E.A. 2006. Carbon allocation to ectomycorrhizal fungi correlates with belowground allocation in culture studies. Ecology 87: 563-9.

Houston, D.R. 1987. Forest tree declines of past and present: current understanding. Can. J. Plant Pathol. 9: 349-360.

Houston, D.R. 1999. History of Sugar Maple Decline. In Sugar Maple Ecology and Health: Proceedings of an International Symposium. Edited by Stephen B. Horsley and Robert P. Long, pages 19-26. USDA Forest Service Northeastern Research Station, General Technical Report NE-261.

Jiao, Y., Whalen, J.K., and Hendershot, W.H. 2007. Phosphate sorption and release in a sandy-loam soil as influenced by fertilizer sources. Soil Sci. Soc. Am. J. 71: 118-124. doi:10.2136/sssaj2006.0028.

Juice, S.M., Fahey, T.J., Siccama, T.G., Driscoll, C.T., Denny, E.G., Eagar, C., Cleavitt, N.L., Minocha, R., and Richardson, A.D. 2006. Response of sugar maple to calcium addition to northern hardwood forest. Ecology 87: 1267-1280. doi:10.1890/00129658(2006)87[1267:ROSMTC]2.0.CO;2.

Karnig, J.J. 1972. Nitrogen fertilizer increases diameter growth of northern red oak. J. For. 70: 629.

Kobe, R.K., Likens, G.E., and Eagar, C. 2002. Tree seedling growth and mortality responses to manipulations of calcium and aluminum in a northern hardwood forest. Can. J. For. Res. 32: 954-966. doi:10.1139/x02-018.

Lea, R., Tierson, W.C., and Leaf, A.L. 1979. Growth responses of northern hardwoods to fertilization. For. Sci. 25: 597-604.

LeBauer, D.S., and Treseder, K.K. 2008. Nitrogen limitation of net primary productivity in terrestrial ecosystems is globally distributed. Ecology 89: 371-379. doi:10.1890/06-2057.1.

Leech, R., and Kim, Y. 1990. Methods to investigate fertilization as a means to improve growth and sugar yield of sugar maple. Commun. Soil Sci. Plan. 21: 20292051.

Lovett, G.M., Weathers, K.C., Arthur, M.A., and Schultz, J.C. 2004. Nitrogen cycling in a northern hardwood forest: Do species matter? Biogeochemistry 67: 289308. doi:10.1023/B:BIOG.0000015786.65466.f5.

Mader, D.L., Thompson, B.W., and Wells, J.P. 1969. Influence of nitrogen on sugar maple decline. Massachusetts Agricultural Experiment Station Bulletin 582: 1-19.

Magill, A.H., Aber, J.D., Currie, W.S., Nadelhoffer, K.J., Martin, M.E., Mcdowell, W.H., Melillo, J.M., and Steudler, P. 2004. Ecosystem response to 15 years of chronic nitrogen additions at the Harvard Forest LTER, 
Massachusetts, USA. For. Ecol. Manage. 196: 7-28. doi:10.1016/j.foreco.2004.03.033.

Magnani, F., Mencuccini, M., Borghetti, M., Berbigier, P., Berninger, F., Delzon, S., Grelle, A., Hari, P., Jarvis, P.G., Kolari, P., Kowalski, A.S., Lankreijer, H., Law, B.E., Lindroth, A., Loustau, D., Manca, G., Moncrieff, J.B., Rayment, M., Tedeschi, V., Valentini, R., and Grace, J. 2007. The human footprint in the carbon cycle of temperate and boreal forests. Nature 447: 848-50. doi:10.1038/nature05847.

Mercer, R.D. 1974. Foliar nutrient levels and fertilization response of sugar maple in a mixed hardwood stand in central New Brunswick. M.S. Thesis. Fredericton, NB: University of New Brunswick.

Mitchell, H.L., and Chandler, R.F. 1939. The nitrogen nutrition and growth of certain deciduous trees of northeastern United States. Black Rock Forest Papers $1(11)$.

Mitchell, M.J., Driscoll, C.T., Owen, J.S., Schaefer, D., Michener, R., and Raynal, D.J. 2001. Nitrogen biogeochemistry of three hardwood ecosystems in the Adirondack Region of New York. Biogeochemistry 56: 93-133. doi:10.1023/A:1013001710569.

Mohren, G.M., Burg, J., and Burger, F.W. 1986. Phosphorus deficiency induced by nitrogen input in Douglas fir in the Netherlands. Plant Soil 95: 191-200. doi:10.1007/BF02375071.

Moore, J., and Houle, D. 2009. Soil solution and sugar maple response to $\mathrm{NH} 4 \mathrm{NO} 3$ additions in a base-poor northern hardwood forest of Québec, Canada. Environ. Monit. Assess. 155: 177-190. doi:10.1007/s10661-0080427-y.

Moore, J., and Ouimet, R. 2006. Ten-year effect of dolomitic lime on the nutrition, crown vigor, and growth of sugar maple. Can. J. For. Res. 36: 1834-1841. doi:10.1139/X06-081.

Naples, B.K., and Fisk, M.C. 2010. Belowground insights into nutrient limitation in northern hardwood forests. Biogeochemistry: 97: 109-121. doi:10.1007/s10533-0099354-4.

Nave, L.E., Vance, E.D., Swanston, C.W., and Curtis, P.S. 2010. Harvest impacts on soil carbon storage in temperate forests. For. Ecol. Manage. 259: 857-866. doi:10.1016/j.foreco.2009.12.009.

Olson, D.M., Dinerstein, E., Wikramanayake, E.D., Burgess, N.D., Powell, G.V., Underwood, E.C., D'Amico, J.A., et al. 2001. Terrestrial Ecoregions of the World: A New Map of Life on Earth. BioScience 51: 933-938. doi:10.1641/00063568(2001)051[0933:TEOTWA]2.0.CO;2.

Ouimet, R., and Fortin, J. 1992. Growth and foliar nutrient status of sugar maple: incidence of forest decline and reaction to fertilization. Can. J. For. Res. 22: 699-706. doi:10.1139/x92-093.

Paré, D., and Bernier, B. 1989. Origin of the phosphorus deficiency observed in declining sugar maple stands in the Quebec Appalachians. Can. J. For. Res. 19: 24-34. doi:10.1139/x89-004.

Paul, E.A., ed. 2007. Soil Microbiology, Ecology, and Biogchemistry. Academic Press.

Payette, S., Fortin, M., and Morneau, C. 1996. The recent sugar maple decline in southern Quebec: probable causes deduced from tree rings. Can. J. For. Res.26: 1069-1078. doi:10.1139/x26-118.

Pregitzer, K.S., Burton, A.J., Zak, D.R., and Talhelm, A.F. 2008. Simulated chronic nitrogen deposition increases carbon storage in Northern Temperate forests. Glob. Change Biol. 14: 142-153. doi:10.1111/j.13652486.2007.01465.x.

Rosenthal, R. 1979. The file drawer problem and tolerance for null results. Psychol. Bull. 86: 638-641. doi:10.1037/0033-2909.86.3.638.

Safford, L.O. 1973. Fertilization increases diameter growth of beech-birch-maple trees in New Hampshire. USDA Forest Service Research Note NE-182.

Safford, L.O. 1982. Correlation of greenhouse bioassay with field response to fertilizer by paper birch. Plant Soil 64: 167-176. doi:10.1007/BF02184248.

Safford, L., and Czapowskyj, M. 1986. Fertilizer stimulates growth and mortality in a young Populus-Betula stand: 10-year results. Can. J. For. Res. 16: 807-813. doi:10.1139/x86-143.

Safford, L.O., and Filip, S.M. 1974. Biomass and nutrient content of 4-year-old fertilized and unfertilized northern hardwood stands. Can. J. For. Res. 4: 549-554. doi:10.1139/x74-079.

Salonius, P.O., Fisher, R.A., and Mahendrappa, M.K. 1982. An alternative method of measuring fertilizer effects in forest stands. Can. J. For. Res. 12: 146-150. doi:10.1139/x82-022.

Schmitt, M.D., Czapowskyj, M.M., Safford, L.O., and Leaf, A.L. 1981. Biomass and elemental uptake in fertilized and unfertilized Betula papyrifera Marsh. and Populus grandidentata Michx. Plant Soil 60: 111-121. doi:10.1007/BF02377116.

Sparks, D.L. 2003. Environmental Soil Chemistry. Academic Press.

St.Clair, S.B., Sharpe, W.E., and Lynch, J.P. 2008. Key interactions between nutrient limitation and climatic factors in temperate forests: a synthesis of the sugar maple literature. Can. J. For. Res. 38: 401-414. doi:10.1139/X07-161. 
Stanturf, J.A. 1983. Effects of added nitrogen on trees and soil of deciduous forests in southern New York. Ph.D. Dissertation. Ithaca, NY: Cornell University.

Stevens, P.A., Harrison, A.F., Jones, H.E., Williams, T., and Hughes, S. 1993. Nitrate leaching from a Sitka spruce plantation and the effect of fertilisation with phosphorus and potassium. For. Ecol. Manage. 58: 233247. Stone, D.M. 1980. Fertilization of a pole-sized maple stand: 10-year results. Can. J. For. Res. 10: 158163. doi:10.1139/x80-028.

Stone, D.M. 1980. Fertilization of a pole-sized maple stand: 10-year results. Can. J. For. Res. 10: 158-163. doi:10.1139/x80-028.

Thomas, R.Q., Canham, C.D., Weathers, K.C., and Goodale, C.L. 2010. Increased tree carbon storage in response to nitrogen deposition in the US. Nature Geosci 3:3-17. doi:10.1038/ngeo721.

Tilman, D. 1985. The resource-ratio hypothesis of plant succession. Am. Nat. 125: 827-852.

Treseder, K.K., and Vitousek, P.M. 2001. Effects of Soil Nutrient Availability on Investment in Acquisition of $\mathrm{N}$ and $\mathrm{P}$ in Hawaiian Rain Forests. Ecology 82: 946-954. doi:10.1890/00129658(2001)082[0946:EOSNAO]2.0.CO;2.

Treseder, K.K. 2004. A meta-analysis of mycorrhizal responses to nitrogen, phosphorus, and atmospheric CO2 in field studies. New Phytol. 164: 347-355. doi:10.1111/j.1469-8137.2004.01159.x.

Tripler, C.E., Canham, C.D., Inouye, R.S., and Schnurr, J.L. 2002. Soil nitrogen availability, plant luxury consumption, and herbivory by white-tailed deer. Oecologia 133: 517-524. doi:10.1007/s00442-002-1046$\mathrm{x}$.

Vitousek, P.M., Hättenschwiler, S., Olander, L., and Allison, S. 2002. Nitrogen and nature. Ambio 31: 97-101.

Vitousek, P.M., and Farrington, H. 1997. Nutrient limitation and soil development: Experimental test of a biogeochemical theory. Biogeochemistry 37: 63-75. doi:10.1023/A:1005757218475.

Vitousek, P.M., and Howarth, R.W. 1991. Nitrogen limitation on land and in the sea: How can it occur? Biogeochemistry 13: 87-115. doi:10.1007/BF00002772.

Walker, T.W., and Syers, J.K. 1976. The fate of phosphorus during pedogenesis. Geoderma 15: 1-19.

Wallace, Z.P., Lovett, G.M., Hart, J.E., and Machona, B. 2007. Effects of nitrogen saturation on tree growth and death in a mixed-oak forest. For. Ecol. Manage. 243: 210-218. doi:10.1016/j.foreco.2007.02.015.

Ward, W.W., and Bowersox, T.W. 1970. Upland oak response to fertilization with nitrogen, phosphorus, and calcium. For. Sci. 16: 113-120. doi:10.1139/x88-116.

Wilmot, T.R., Ellsworth, D.S., and Tyree, M.T. 1996. Base cation fertilization and liming effects on nutrition and growth of Vermont sugar maple stands. For. Ecol. Manage. 84: 123- 134. doi:10.1016/03781127(96)03743-7.

Zaccherio, M.T., and Finzi, A.C. 2007. Atmospheric deposition may affect northern hardwood forest composition by altering soil nutrient supply. Ecological Applications 17: 1929-41. doi:10.1890/06-2067.1. 
Table 1. Experiments included in the meta-analysis. Species codes are explained in Table 3.

\begin{tabular}{|c|c|c|c|c|c|c|c|c|c|}
\hline$\#$ & Reference & Location(s) & $\begin{array}{l}\text { Species (not } \\
\text { necessarily all } \\
\text { used here) }\end{array}$ & $\begin{array}{l}\text { Stand or } \\
\text { cohort } \\
\text { age }\end{array}$ & design & $\begin{array}{l}\text { fert. } \\
\text { schedule }\end{array}$ & $\begin{array}{l}\text { growing } \\
\text { seasons }\end{array}$ & $\begin{array}{l}\text { usable } \\
\text { reported } \\
\text { obs. }\end{array}$ & $\begin{array}{l}\text { Conclus-ions } \\
\text { re: limiting } \\
\text { resources }\end{array}$ \\
\hline 1 & $\begin{array}{l}\text { Bigelow and } \\
\text { Canham } 2007\end{array}$ & $\begin{array}{l}\text { Great } \\
\text { Mountain } \\
\text { Forest (CT) }\end{array}$ & $\begin{array}{l}\text { QURU, ACRU, } \\
\text { ACSA, FRAM, } \\
\text { FAGR, TSCA, } \\
\text { PIST }\end{array}$ & saplings & $\begin{array}{l}\mathrm{N} \times \mathrm{Ca} \\
\text { factorial }\end{array}$ & continual & 3 & 7 & $\mathrm{Ca}$ and $\mathrm{N}$ \\
\hline 2 & Côté et al. 1995 & $\begin{array}{l}\text { Entrelacs } \\
\text { (QUE) }\end{array}$ & ACSA & 110 & $\begin{array}{l}\mathrm{N}, \mathrm{Ca} \\
\text { separately }\end{array}$ & pulse & 5 & 2 & not $\mathrm{Ca}$ or $\mathrm{N}$ \\
\hline 3 & Ellis et al. 1979 & $\begin{array}{l}\text { Grey County } \\
\text { (ONT) }\end{array}$ & $\begin{array}{l}\text { ACSA, FRAM, } \\
\text { PRSE }\end{array}$ & $35-85$ & NPCa & pulse & 5 & 6 & $\mathrm{~N}$; not-N \\
\hline 4 & Elvir et al. 2003 & $\begin{array}{l}\text { Bear Brook } \\
\text { (ME) }\end{array}$ & ACSA & mature & $\mathrm{N}$ & continual & 10 & 1 & $\mathrm{~N}$; not-N \\
\hline 5 & $\begin{array}{l}\text { Fahey et al. } \\
1998\end{array}$ & $\begin{array}{l}\text { White } \\
\text { Mountains } \\
\text { (NH) }\end{array}$ & $\begin{array}{l}\text { PRPE. BEPA, } \\
\text { BEAL, FAGR, } \\
\text { ACSA, ACPE }\end{array}$ & $6-23$ & NPCa & continual & 5 & 3 & $\begin{array}{l}\text { one or more } \\
\text { of } N, P, K, C a \text {, } \\
M g\end{array}$ \\
\hline 6 & $\begin{array}{l}\text { Finn and Tyron } \\
1942\end{array}$ & $\begin{array}{l}\text { Black Rock } \\
\text { Forest (NY) }\end{array}$ & QURU & 43 & $\begin{array}{l}\mathrm{N} \text { and } \mathrm{P} \\
\text { separately }\end{array}$ & pulse & 3 & 3 & $\begin{array}{l}\text { Ca and/or P; } \\
\mathrm{N}\end{array}$ \\
\hline 7 & $\begin{array}{l}\text { Finn and White } \\
1966\end{array}$ & $\begin{array}{l}\text { southwest } \\
\text { MI }\end{array}$ & $\begin{array}{l}\text { LITU } \\
\text { (plantation) }\end{array}$ & 20 & $\mathrm{~N}$ and NPK & pulse & 5 & 4 & $\mathrm{~N}$ \\
\hline 8 & Finzi 2009 & $\begin{array}{l}\text { Great } \\
\text { Mountain } \\
\text { Forest (CT) }\end{array}$ & $\begin{array}{l}\text { ACSA, FRAM, } \\
\text { QURU, FAGR, } \\
\text { TSCA }\end{array}$ & 120 & $\begin{array}{l}\text { NxP full } \\
\text { factorial }\end{array}$ & continual & 2 & 6 & $\begin{array}{l}\text { primarily } \mathrm{N} \text {; } \\
\text { secondarily } \mathrm{P}\end{array}$ \\
\hline 9 & Fyles et al. 1994 & $\begin{array}{l}\text { Station } \\
\text { Biologique } \\
\text { des } \\
\text { Laurentides } \\
\text { (QUE) }\end{array}$ & ACSA & 80 & $\begin{array}{l}\text { base } \\
\text { cations } \\
\text { only }\end{array}$ & pulse & 3 & 1 & $\begin{array}{l}\mathrm{Ca}, \mathrm{pH} \text { or } \\
\text { other base } \\
\text { cations }\end{array}$ \\
\hline 10 & $\begin{array}{l}\text { Gradowski and } \\
\text { Thomas } 2008\end{array}$ & $\begin{array}{l}\text { Halliburton } \\
\text { Forest (ONT) }\end{array}$ & ACSA & mature & $\begin{array}{l}\text { PxCa full } \\
\text { factorial }\end{array}$ & continual & 2 & 3 & not $P$ \\
\hline 11 & Juice et al. 2006 & $\begin{array}{l}\text { Hubbard } \\
\text { Brook (NH) }\end{array}$ & $\begin{array}{l}\text { ACSA, FAGR, } \\
\text { BEAL }\end{array}$ & 1 & $\mathrm{Ca}$ & pulse & 5 & 1 & Ca and/or $\mathrm{pH}$ \\
\hline 12 & Karnig 1972 & $\begin{array}{l}\text { Black Rock } \\
\text { Forest (NY) }\end{array}$ & QURU & mature & $\mathrm{N}$ & pulse & 6 & 1 & $N$ \\
\hline 13 & Kobe et al. 2002 & $\begin{array}{l}\text { Hubbard } \\
\text { Brook (NH) }\end{array}$ & $\begin{array}{l}\text { ACSA, FAGR, } \\
\text { BEAL }\end{array}$ & 2 & $\mathrm{Ca}$ & continual & 2 & 3 & $\mathrm{Ca}$ \\
\hline 14 & $\begin{array}{l}\text { Lea, Tierson, } \\
\text { and Leaf } 1979\end{array}$ & $\begin{array}{l}\text { Huntington } \\
\text { Forest (NY) }\end{array}$ & $\begin{array}{l}\text { BEAL, ACRU, } \\
\text { ACSA, FAGR }\end{array}$ & 70 & $\begin{array}{l}\text { NxPxCa full } \\
\text { factorial }\end{array}$ & pulse & 2 & 5 & $\mathrm{~N} ; \mathrm{P}$ \\
\hline 15 & $\begin{array}{l}\text { Leech and Kim } \\
1990\end{array}$ & Flos (ONT) & ACSA & 100 & $\begin{array}{l}\text { NxPxCa } \\
\text { partial } \\
\text { factorial }\end{array}$ & continual & 6 & 2 & $\mathrm{~N}$ or $\mathrm{N}+\mathrm{P}$ \\
\hline 16 & $\begin{array}{l}\text { Mader et al. } \\
1969\end{array}$ & Conway (MA) & ACSA & mature & NPK only & pulse & 2 & 1 & $N$ \\
\hline 17 & $\begin{array}{l}\text { Magill et al. } \\
2004\end{array}$ & $\begin{array}{l}\text { Harvard } \\
\text { Forest (MA) }\end{array}$ & $\begin{array}{l}\text { QURU, QUVE, } \\
\text { ACRU, FAGR, } \\
\text { BELE }\end{array}$ & 90 & $\mathrm{~N}$ & continual & 14 & 2 & $N$ \\
\hline 18 & Mercer 1974 & central NB & ACSA & 37 & $\begin{array}{l}\mathrm{NxP} \\
\text { factorial }\end{array}$ & pulse & 2 & 3 & $\mathrm{~N}$ \\
\hline 19 & $\begin{array}{l}\text { Mitchell and } \\
\text { Chandler } 1939\end{array}$ & $\begin{array}{l}\text { Black Rock } \\
\text { Forest, Arnot } \\
\text { Forest (NY) }\end{array}$ & $\begin{array}{l}\text { ACRU, ACSA, } \\
\text { CAGL, FAGR, } \\
\text { FRAM, LITU, } \\
\text { NYSY, POTR, } \\
\text { QU**, TIAM }\end{array}$ & $35-60$ & $N$ & pulse & 2 & $38^{*}$ & $N$ \\
\hline 20 & $\begin{array}{l}\text { Mitchell et al. } \\
2001\end{array}$ & $\begin{array}{l}\text { Huntington } \\
\text { Forest (NY) }\end{array}$ & $\begin{array}{l}\text { FAGR, BEAL } \\
\text { ACSA, ACRU }\end{array}$ & 70 & $\mathrm{~N}$ & continual & 3 & 2 & not-N \\
\hline
\end{tabular}


Table 1, continued.

\begin{tabular}{|c|c|c|c|c|c|c|c|c|c|}
\hline 21 & $\begin{array}{l}\text { Moore and } \\
\text { Houle } 2009\end{array}$ & $\begin{array}{l}\text { Lake Clair } \\
\text { watershed } \\
\text { (QUE) }\end{array}$ & $\begin{array}{l}\text { ACSA, FAGR, } \\
\text { BEAL }\end{array}$ & mature & $\mathrm{N}$ & continual & 3 & 2 & not-N \\
\hline 22 & $\begin{array}{l}\text { Moore and } \\
\text { Ouimet } 2006\end{array}$ & $\begin{array}{l}\text { Lake Clair } \\
\text { watershed } \\
\text { (QUE) }\end{array}$ & ACSA & mature & $\mathrm{Ca}$ & continual & 10 & 7 & $\mathrm{Ca}, \mathrm{Mg}$, or $\mathrm{pH}$ \\
\hline 23 & $\begin{array}{l}\text { Ouimet and } \\
\text { Fortin } 1992\end{array}$ & $\begin{array}{l}\text { Beauce } \\
\text { (QUE) }\end{array}$ & ACSA & mature & $\begin{array}{l}\mathrm{P}+\text { base } \\
\text { cations }\end{array}$ & pulse & 2 & 1 & $\begin{array}{l}\mathrm{P}, \mathrm{K}, \mathrm{Ca}, \mathrm{Mg} \text {, } \\
\text { or } \mathrm{pH}\end{array}$ \\
\hline 24 & $\begin{array}{l}\text { Pregitzer et al. } \\
2008\end{array}$ & $\begin{array}{l}\text { Michigan } \\
\text { Gradient } \\
\text { Study }\end{array}$ & primarily ACSA & 90 & $\mathrm{~N}$ & continual & 10 & 4 & $\mathrm{~N}$ \\
\hline 25 & Safford 1973 & Bartlett (NH) & $\begin{array}{l}\text { BEAL, BEPA, } \\
\text { ACSA, FAGR }\end{array}$ & 60 & $\begin{array}{l}\mathrm{NxPxCa} \\
\text { partial } \\
\text { factorial }\end{array}$ & pulse & 7 & 8 & $\begin{array}{l}\text { one or more } \\
\text { of } \mathrm{N}, \mathrm{P}, \mathrm{K} \text {. } \\
\text { Also } \mathrm{Ca} \text { or } \mathrm{pH} \\
\text { effect }\end{array}$ \\
\hline 26 & Safford 1982 & $\begin{array}{l}\text { Bartlett (NH) } \\
\text { and } \\
\text { Massabesic } \\
\text { (ME) }\end{array}$ & BEPA & 7 & $\begin{array}{l}\mathrm{NxPxCa} \\
\text { partial } \\
\text { factorial }\end{array}$ & pulse & 3 & 14 & $\begin{array}{l}\text { Bartlett: } \mathrm{N} \text {, } \\
\text { then P. } \\
\text { Massabesic: } \\
\mathrm{N} \text { only }\end{array}$ \\
\hline 27 & $\begin{array}{l}\text { Safford and } \\
\text { Czapowskyj } \\
1986\end{array}$ & $\begin{array}{l}\text { Clifford Burn } \\
\text { (ME) }\end{array}$ & $\begin{array}{l}\text { POGR, POTR, } \\
\text { BEPA, ACRU }\end{array}$ & 14 & $\begin{array}{l}\text { NxPxCa full } \\
\text { factorial }\end{array}$ & continual & 10 & 28 & $\begin{array}{l}\text { ranked by } \\
\text { number of } \\
\text { signficant } \\
\text { effects: } \\
\mathrm{N}+\mathrm{P}+\mathrm{Ca}, \mathrm{N}, \\
\mathrm{P}+\mathrm{Ca}+\mathrm{Mg}, \\
\mathrm{Ca}+\mathrm{Mg}\end{array}$ \\
\hline 28 & $\begin{array}{l}\text { Safford and Filip } \\
1974\end{array}$ & Bartlett (NH) & $\begin{array}{l}\text { PRPE, BEPA, } \\
\text { BEAL }\end{array}$ & just cut & NPK lime & pulse & 4 & 1 & $\begin{array}{l}\text { one or more } \\
\text { of NPK. Also } \\
\text { Ca or pH } \\
\text { effect }\end{array}$ \\
\hline 29 & $\begin{array}{l}\text { Schmitt et al. } \\
1981\end{array}$ & $\begin{array}{l}\text { Clifford Burn } \\
\text { (ME) }\end{array}$ & POGR, BEPA & 22 & NPK lime & pulse & 4 & 2 & $\begin{array}{l}\text { one or more } \\
\text { of } \mathrm{N}, \mathrm{P}, \mathrm{Ca} \text {, or } \\
\mathrm{pH}\end{array}$ \\
\hline 30 & Stanturf 1983 & $\begin{array}{l}\text { multiple sites } \\
\text { (NY) }\end{array}$ & $\begin{array}{l}\text { ACSA, FRAM, } \\
\text { PRSE, QURU, } \\
\text { TIAM }\end{array}$ & 100 & $N$ & pulse & 10 & 18 & $\mathrm{~N}$ and non- $\mathrm{N}$ \\
\hline 31 & Stone 1980 & Hurley (WI) & ACSA, ACRU & 48 & $\begin{array}{l}\text { NxP full } \\
\text { factorial }\end{array}$ & pulse & 10 & 3 & $\mathrm{~N} ; \mathrm{P}$ ? \\
\hline 32 & $\begin{array}{l}\text { Tripler et al. } \\
2002\end{array}$ & $\begin{array}{l}\text { Great } \\
\text { Mountain } \\
\text { Forest (CT) }\end{array}$ & $\begin{array}{l}\text { BEAL, FAGR, } \\
\text { PRSE, QURU }\end{array}$ & sapings & $\mathrm{N}$ & pulse & 1 & 8 & $\mathrm{~N}$; not- $\mathrm{N}$ \\
\hline 33 & $\begin{array}{l}\text { Wallace et al. } \\
2007\end{array}$ & $\begin{array}{l}\text { Millbrook } \\
\text { (NY) }\end{array}$ & $\begin{array}{l}\text { QUPR, QURU, } \\
\text { CA**, ACSA, } \\
\text { ACRU, PIST }\end{array}$ & $60-80$ & $N$ & continual & 8 & 1 & not-N \\
\hline 34 & $\begin{array}{l}\text { Wilmot et al. } \\
1996\end{array}$ & $\begin{array}{l}\text { multiple sites } \\
\text { (VT) }\end{array}$ & ACSA & mature & $\begin{array}{l}\mathrm{Ca}, \mathrm{Mg} \text {, } \\
\text { and } \mathrm{K}\end{array}$ & continual & 3 & 2 & $\begin{array}{l}\mathrm{Ca}, \mathrm{Mg}, \\
\text { and/or K. } \\
\text { Larger pH } \\
\text { effect }\end{array}$ \\
\hline 35 & $\begin{array}{l}\text { Zaccherio and } \\
\text { Finzi } 2007\end{array}$ & $\begin{array}{l}\text { Great } \\
\text { Mountain } \\
\text { Forest and } \\
\text { Housatonic } \\
\text { State Forest } \\
\text { (CT) }\end{array}$ & $\begin{array}{l}\text { ACSA, ACRU, } \\
\text { QURU }\end{array}$ & $\begin{array}{l}3-6 \mathrm{yr} \\
\text { seedlings }\end{array}$ & $\begin{array}{l}\mathrm{N} \times \mathrm{Ca} \text { full } \\
\text { factorial }\end{array}$ & continual & 4 & 24 & $\begin{array}{l}\mathrm{N} \text { for red } \\
\text { maple, Ca for } \\
\text { sugar maple }\end{array}$ \\
\hline
\end{tabular}

* only observations based on at least 5 trees in each the control and treatment were used from Mitchell and Chandler 1939.

** indicates multiple species of a given genus, e.g. AC** = multiple Acer species. This convention is used either where species are not listed in the cited text, or where more than three species in a given genus are listed. 
Table 2. Number of observations by added element, scale of observation (stand vs. tree), direction of effect, and reported significance and variance. Also included is the number of observations in each category that include variance data, and can therefore be included in a formal meta-analysis.

\begin{tabular}{clllll} 
& total $n$ & positive & $\begin{array}{l}\text { sig. } \\
\text { positive }\end{array}$ & $\begin{array}{l}\text { sig. } \\
\text { negative }\end{array}$ & $\begin{array}{l}\text { variance } \\
\text { reported }\end{array}$ \\
Nitrogen & 154 & 132 & 63 & 4 & 73 \\
\hline N only & 100 & 84 & 34 & 3 & 60 \\
trees & 85 & 71 & 31 & 3 & 53 \\
stands & 15 & 13 & 3 & 0 & 7 \\
N plus other nutrients & 54 & 48 & 29 & 1 & 13 \\
trees & 32 & 28 & 19 & 1 & 6 \\
stands & 22 & 20 & 10 & 0 & 7
\end{tabular}

\begin{tabular}{clllll} 
Phosphorus & 58 & 52 & 23 & 0 & 12 \\
\hline P “only" (with Ca) & 12 & 8 & 1 & 0 & 3 \\
trees & 6 & 4 & 0 & 0 & 1 \\
stands & 6 & 5 & 1 & 0 & 2 \\
P plus other nutrients & 46 & 44 & 22 & 0 & 9 \\
trees & 24 & 23 & 11 & 0 & 2 \\
stands & 22 & 20 & 11 & 0 & 7
\end{tabular}

\begin{tabular}{clllll} 
Calcium & 74 & 62 & 37 & 3 & 32 \\
\hline Ca only & 31 & 24 & 14 & 2 & 18 \\
trees & 27 & 21 & 13 & 2 & 18 \\
stands & 4 & 3 & 1 & 0 & 0 \\
Ca plus other nutrients & 43 & 38 & 23 & 1 & 14 \\
trees & 22 & 17 & 12 & 1 & 7 \\
stands & 21 & 21 & 11 & 0 & 7
\end{tabular}


Table 3. Number of observations by species, along with mean response ratios and their associated confidence intervals. Data were log-transformed before calculating means and standard errors. Bold text indicates a mean R significantly different from 1.0.

\begin{tabular}{|c|c|c|c|c|c|c|c|c|c|c|c|c|c|c|c|c|c|}
\hline & \multirow[b]{2}{*}{ Species } & \multirow{2}{*}{$\begin{array}{l}\text { MR } \\
\text { type }\end{array}$} & \multirow{2}{*}{$\begin{array}{l}\text { total } \\
\text { studies }\end{array}$} & \multicolumn{2}{|r|}{$\begin{array}{l}\text { single- } \\
\text { species }\end{array}$} & \multicolumn{3}{|c|}{$\mathrm{N}$ only } & \multicolumn{3}{|c|}{ P only } & \multicolumn{3}{|c|}{ Ca only } & \multicolumn{3}{|c|}{ Multiple } \\
\hline & & & & total obs. & & $\mathrm{n}$ & mean $\mathrm{R}$ & 95\% C.I. & $\mathrm{n}$ & mean $\mathrm{R}$ & 95\% C.I. & $\mathrm{n}$ & mean $\mathrm{R}$ & 95\% C.I. & $\mathrm{n}$ & mean $R$ & 95\% C.I. \\
\hline ACRU & Acer rubrum L. & AM & 10 & 33 & 19 & 8 & 1.25 & $0.86-1.81$ & 1 & 1.12 & & 3 & 0.93 & $0.42-2.07$ & 7 & 1.72 & $1.09-2.69$ \\
\hline ACPE & Acer pensylvanicum L. & AM & 1 & 3 & 0 & & & & & & & & & & & & \\
\hline ACSA & Acer saccharum Marsh. & $A M$ & 26 & 65 & 46 & 15 & 1.28 & $0.99-1.64$ & 2 & 0.97 & $0.59-1.59$ & 15 & 1.67 & $1.37-2.04$ & 14 & 1.53 & $1.18-1.98$ \\
\hline BEAL & Betula alleghaniensis Britton & EM & 7 & 16 & 5 & 2 & 1.60 & $0.68-3.74$ & & & & 2 & 1.13 & $0.94-1.36$ & 1 & 1.51 & \\
\hline BELE & Betula lenta $\mathrm{L}$. & EM & 1 & 2 & 0 & & & & & & & & & & & & \\
\hline BEPA & Betula papyrifera Marsh. & EM & 8 & 29 & 22 & 3 & 1.69 & $1.19-2.40$ & 3 & 1.06 & $0.91-1.23$ & 4 & 1.06 & $0.90-1.24$ & 14 & 1.73 & $1.45-2.06$ \\
\hline CAGL & Carya glabra (Mill.) Sweet & EM & 1 & 1 & 1 & 1 & 2.50 & & & & & & & & & & \\
\hline CAOV & Carya ovata (Mill.) K. Koch & EM & 1 & 3 & 0 & & & & & & & & & & & & \\
\hline $\mathrm{CA}^{* *}$ & Carya spp. & EM & 1 & 1 & 0 & & & & & & & & & & & & \\
\hline FAGR & Fagus grandifolia Ehrh. & EM & 10 & 26 & 8 & 5 & 1.67 & $1.36-2.61$ & & & & 2 & 1.10 & $0.88-1.37$ & 1 & 1.20 & \\
\hline FRAM & Fraxinus americana $\mathrm{L}$. & AM & 5 & 14 & 11 & 10 & 1.30 & $1.10-1.53$ & & & & & & & 3 & 1.61 & $0.93-2.76$ \\
\hline LITU & Liriodendron tulipifera $\mathrm{L}$. & AM & 2 & 6 & 6 & 4 & 1.55 & $1.29-1.87$ & & & & & & & 2 & 1.46 & $0.75-2.84$ \\
\hline NYSY & Nyssa sylvatica Marsh. & AM & 1 & 1 & 1 & 1 & 1.75 & & & & & & & & & & \\
\hline PIST & Pinus strobus L. * & EM & 1 & 1 & 0 & & & & & & & & & & & & \\
\hline POGR & Populus grandidentata Michx. & EM & 3 & 11 & 8 & 1 & 1.52 & & 1 & 1.35 & & 1 & 1.17 & & 5 & 2.10 & $1.62-2.72$ \\
\hline POTR & Populus tremuloides Michx. & EM & 2 & 12 & 12 & 6 & 1.42 & $1.22-1.66$ & 1 & 1.41 & & 1 & 1.54 & & 4 & 1.94 & $1.31-2.88$ \\
\hline PRPE & Prunus pensylvanica L. f. & AM & 2 & 4 & 0 & & & & & & & & & & & & \\
\hline PRSE & Prunus serotina Ehrh. & $A M$ & 3 & 9 & 6 & 4 & 1.26 & $1.09-1.47$ & & & & & & & 2 & 1.37 & $1.08-1.75$ \\
\hline QUAL & Quercus alba L. & EM & 1 & 1 & 1 & 1 & 1.62 & & & & & & & & & & \\
\hline QUPR & Quercus prinus L. & EM & 2 & 3 & 2 & 2 & 1.62 & $1.38-1.90$ & & & & & & & & & \\
\hline QURU & Quercus rubra L. & EM & 10 & 28 & 22 & 14 & 1.59 & $1.14-2.20$ & 1 & 1.42 & & 2 & 1.30 & $0.29-5.76$ & 3 & 1.45 & $0.32-6.70$ \\
\hline QUVE & Quercus velutina Lam. & EM & 1 & 2 & 0 & & & & & & & & & & & & \\
\hline TIAM & Tilia americana $\mathrm{L}$. & EM & 2 & 8 & 8 & 8 & 1.65 & $1.10-2.48$ & & & & & & & & & \\
\hline TSCA & Tsuga canadensis L. * & EM & 1 & 3 & 0 & & & & & & & & & & & & \\
\hline & Mixed stands & & 9 & 27 & -- & 11 & 1.18 & $1.07-1.30$ & 3 & 1.17 & $0.75-1.83$ & & & & 12 & 1.35 & $1.08-1.70$ \\
\hline
\end{tabular}

* Single-species observations of fertilization effects on conifers are neither included in the meta-analysis nor reported here. However, $P$. strobus and T. canadensis are included in mixed-species stands. 
Table 4. Summary effect direction and significance in single-effect, full multiple, and backward-stepwise reduced multiple regression models. The full multiple model has an adjusted $r^{2}$ of $0.06, p=0.05, A I C=19.5$. The "best multiple" model has an adjusted $r^{2}$ of $0.09, p<0.001$, AIC $=0.3$. P-values $>0.10$ are shown as "ns". Rates of nutrient addition or deposition are in units of $\mathrm{kg} \mathrm{ha}^{-1} \mathrm{yr}^{-1}$.

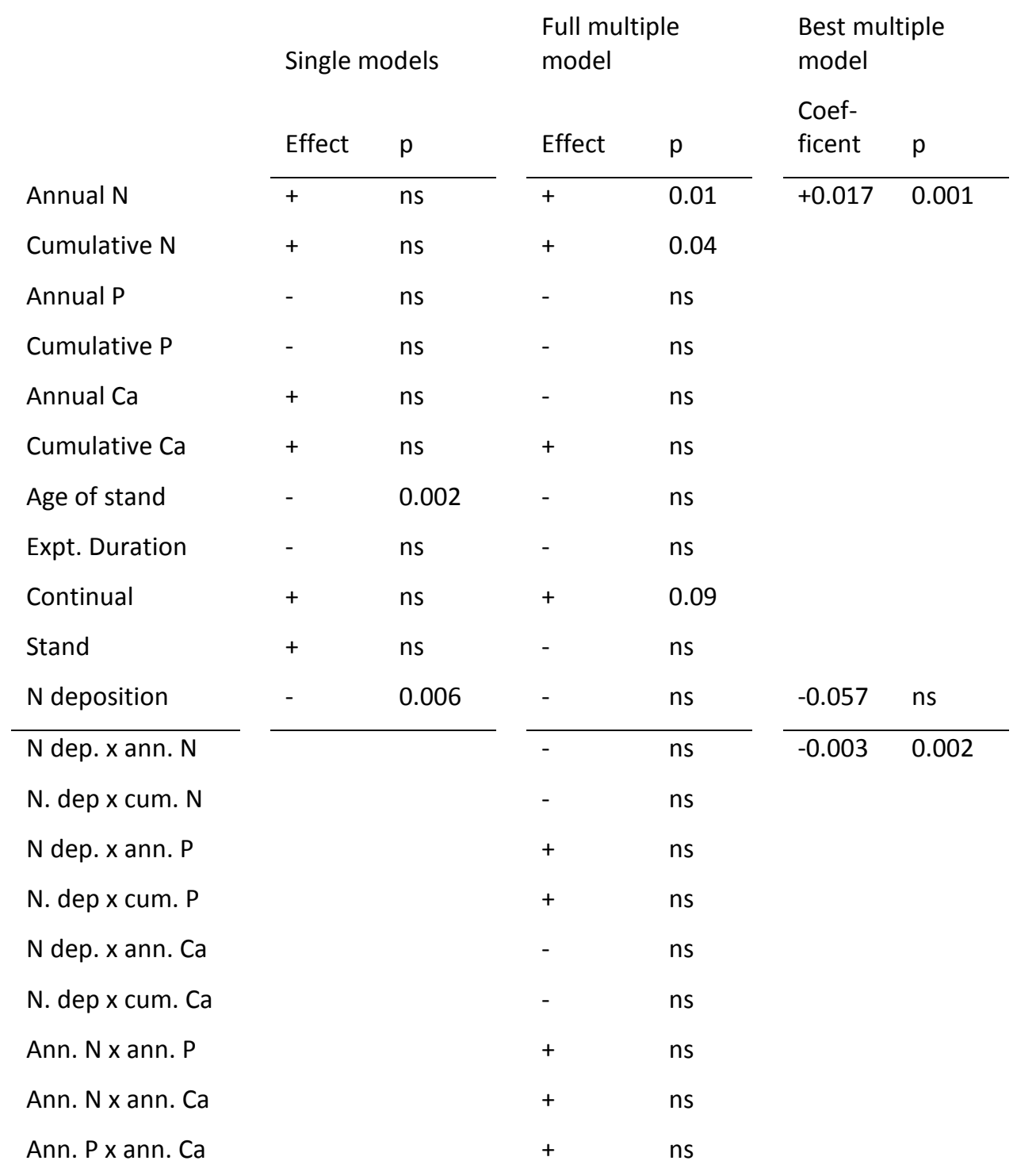

Notes: "Continual" indicates that fertilization was done continually rather than as single pulse. "Stand" indicates that measurement is based on the stand scale rather than at the scale of individual trees. 
Figure 1. Study region with the locations of experiments used in the meta-analysis. Filled symbols indicate locations with at least one study that was included in the formal meta-analysis. Sites represented by open symbols were only included in the simple meta-analyisis. The solid black line is the southern extent of the Wisconsin glaciation (Dyke et al. 2003), and the shaded region is the temperate deciduous and mixed forest biome (Olson et al. 2001). Studies are numbered alphabetically by author (Table 1). Where more than two study sites are within $20 \mathrm{~km}$ of each other, they are mapped as a single location.

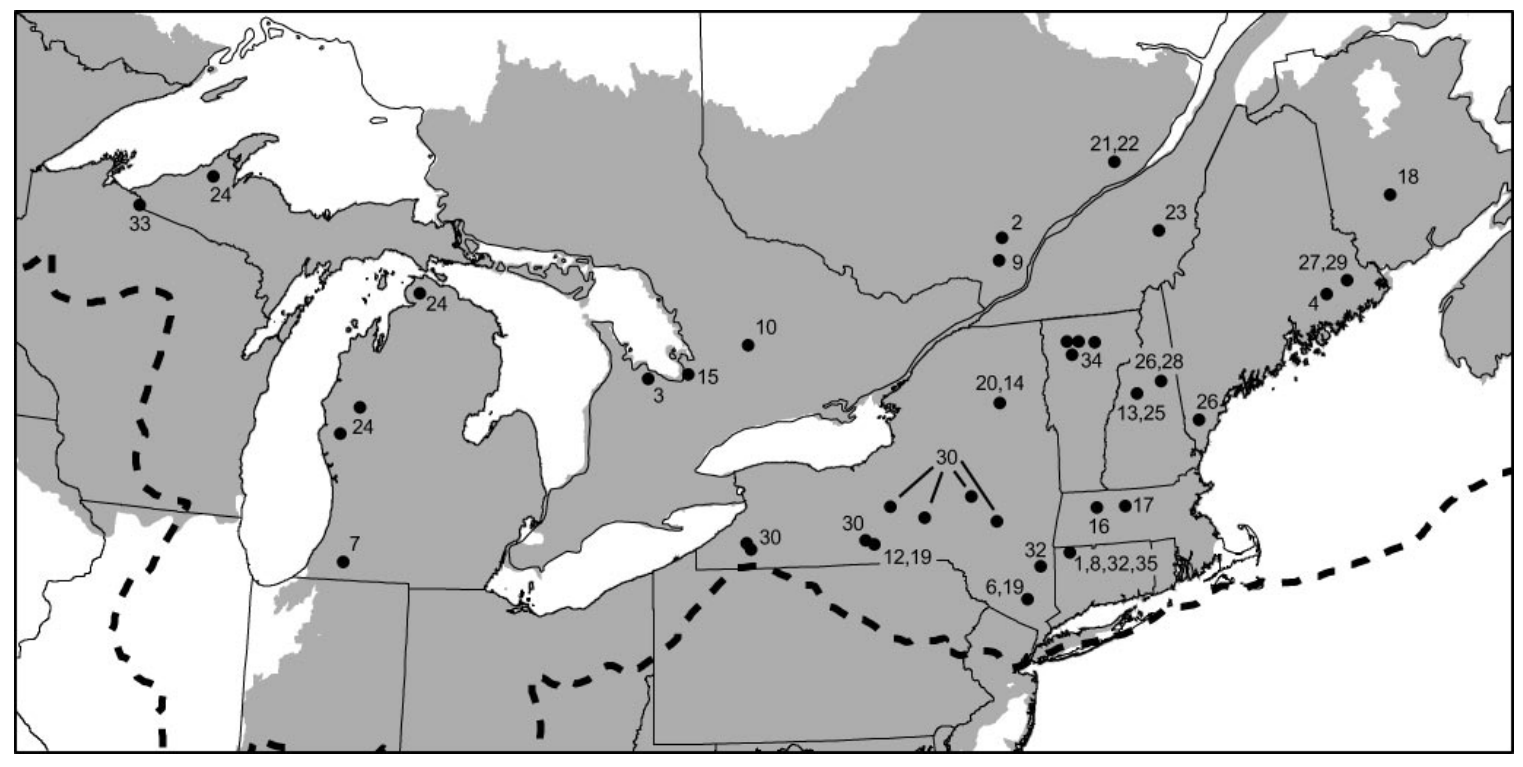


Figure 2. a. Simple mean response ratios calculated across seven categories of nutrient additions, using data from all 35 studies of nutrient additions to forests across the northeastern US and Canada. b. Mean response ratios calculated using a smaller data set (21 studies) where reported sample sizes and variance data allow the use of statistical methods recommended by Hedges et al. (1999). Error bars show $95 \%$ confidence intervals for the mean response ratio.
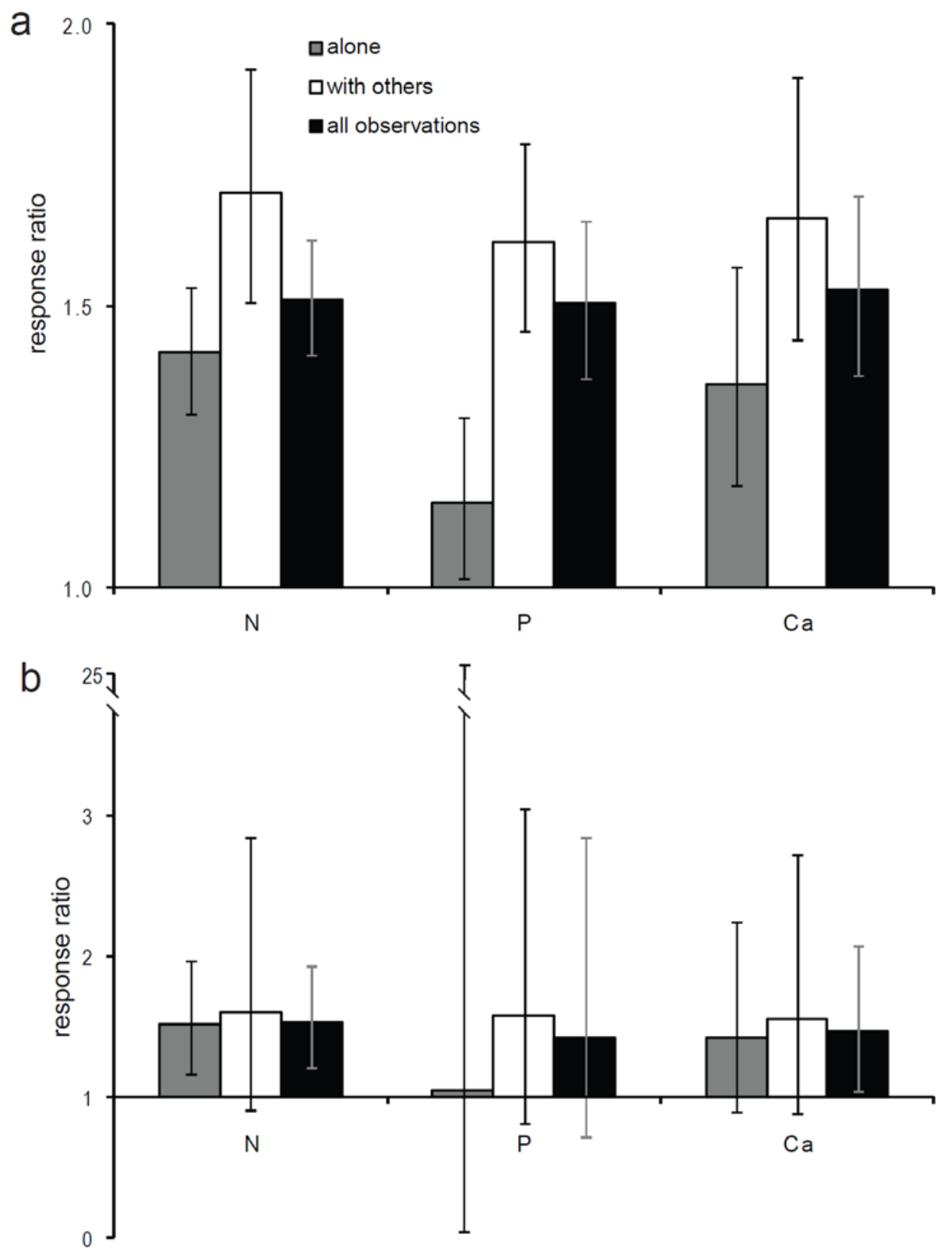
Figure 3. Histograms of the In(response ratio) for four categories of nutrient manipulations. Note that three observations are not included because $\ln$ (response ratio) is undefined when the response variable is negative for either the control or treatment groups. The vertical line at 0 shows the expected mean and mode under the null hypothesis of no fertilizer effect on aboveground NPP. Across all 208 observations, $85 \%$ are positive.

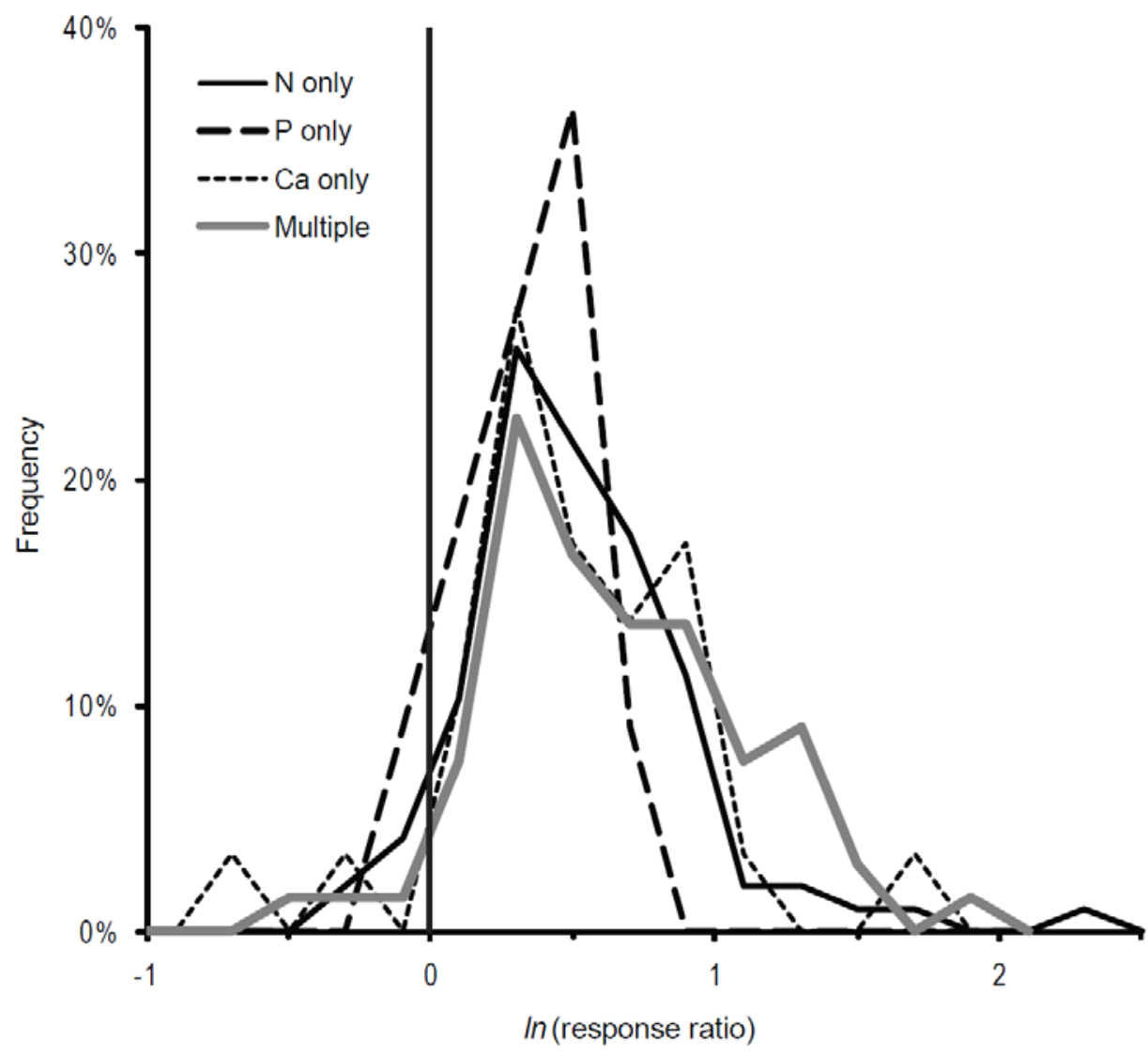


Figure 4. Response ratios vs. addition rate for N, P, and Ca. Note the logarithmic scale on $\mathrm{x}$-axes.
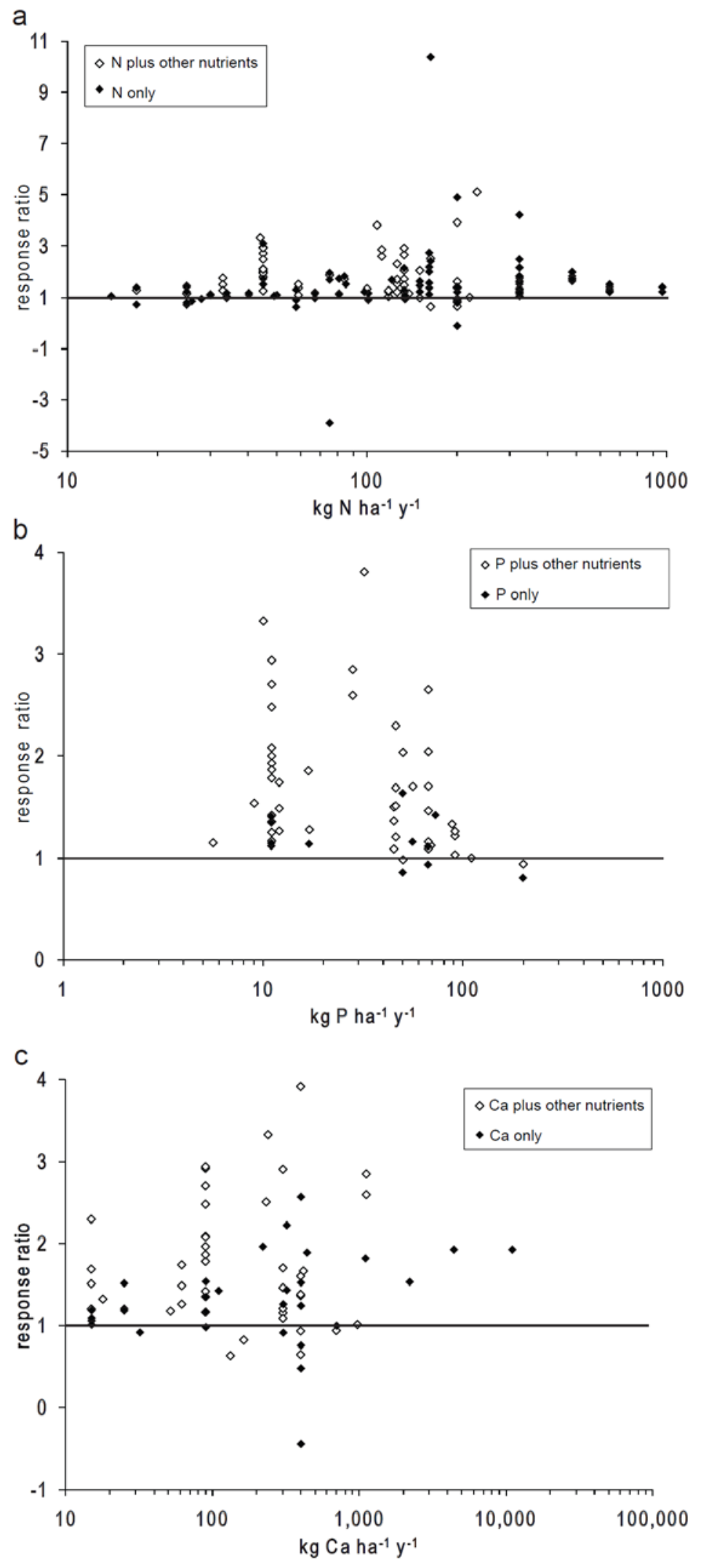